CHALLENGES FOR THE MENTALLY ILL: THE “THREAT

TO SAFETY" DEFENSE STANDARD AND THE USE OF PSYCHOTROPIC MEDICATION UNDER TITLE I OF THE AMERICANS WITH DISABILITIES ACT OF 1990

\author{
KARIN A. GUIDULI $\dagger$
}

\title{
INTRODUCTION
}

Employment is "the key to independence." For the mentally ill, however, the right to employment ${ }^{2}$ has been a conditional one. Like all citizens, the mentally ill have a legitimate need and a right to be productive, working members of society. ${ }^{3}$ By inversely

† B.S. 1993, Northwestern University; J.D. Candidate 1996, University of Pennsylvania. I would like to thank Michael Baughman, Laura Boschken, Timothy De Masi, James Keller, Laurie Malkin, Laura Rabin, Pamela Reichlin, and Margaret Stowers for their support. This Comment is dedicated to my family, with love.

${ }^{1}$ John W. Parry, Employment Under the ADA: A National Perspective, 15 MENTAL \& PhySICAL DISABILITY L. REP. 525, 525 (1991) (discussing the symbolic value of employment).

${ }^{2}$ By speaking of a person's right to be a productive and working member of society, I do not mean to suggest a constitutional liberty interest. To be sure, the Constitution defines liberty broadly enough to guarantee freedom of contract and freedom to pursue an occupation, see Meyer v. Nebraska, 262 U.S. 390, 399 (1923); however, the United States Supreme Court has never held that the Fourteenth Amendment liberty interest creates a constitutional right to have a job. But see Board of Regents v. Roth, 408 U.S. 564, 589 (1972) (Marshall, J., dissenting) ("[L]iberty to work. . . is the 'very essence of the personal freedom and opportunity' secured by the Fourteenth Amendment." (quoting Truax v. Raich, 239 U.S. 33, 41 (1915))). Rather, the purpose of mentioning this "right to work" is to introduce a major premise underlying this Comment that the right to be a productive member of society "goes to the very heart of our way of life." Linehan v. Waterfront Comm., 347 U.S. 439, 441 (1954) (Douglas, J., dissenting). Advocates for the mentally disabled, however, do purport to pursue the "right to ... work where one chooses" as a legal goal. Mental Disability Law: A Primer at i (Commission on the Mentally Disabled, American Bar Ass'n ed., 1984).

${ }^{3}$ It is widely recognized that the significance of employment is both practical and symbolic; the ability to work results not only in income but also in a sense of community participation and self-worth. See Seymour R. Kaplan, Foreword to BERTRAM J. BLACK, WORK AND MENTAL ILLNESS: TRANSITIONS TO EMPLOYMENT at ix, ix-x (1988); Laura L. Mancuso, Reasonable Accommodation for Workers with Psychiatric Disabilities, 14 Psychosocial Rehabilitation J. 3, 3 (1990). Some scholars only grudgingly acknowledge the legitimate place of the mentally ill in society. See THOMAS SZASZ, CRUEL COMPASSION: PSYCHIATRIC CONTROL OF SOCIETY'S UNWANTED 137 (1994) (calling the mentally ill "dependents" and stating that, although they "are human beings and belong in and to society[,] ... it is absurd to value them more highly than the productive members of society"). 
correlating productivity with disability, ${ }^{4}$ however, society has long stigmatized mentally ill individuals and thwarted their search or acceptance and assimilation into regular society. In the employment arena, this stigma often crosses the line into actual discrimination.

On July 26, 1990, this country took a major step toward eliminating such discrimination when President Bush signed into law the Americans with Disabilities Act (the "ADA" or the "Act"). ${ }^{5}$ This landmark enactment marked the bestowment of a "breathtaking promise for people with mental disabilities." Congress noted:

Martin Luther King had a dream. We have a vision. Dr. King dreamed of an America "where a person is judged not by the color of his skin, but by the content of his character." ADA's vision is of an America where persons are judged by their abilities and not on the basis of their disabilities. ${ }^{7}$

${ }^{4}$ See MARTin Roth \& JEROME KRoll, THE REALITY OF MENTAL ILINESS 23 (1986) (noting that our society "defines the productive as 'well' and the unproductive as 'sick'); cf. SzASZ, supra note 3, at xiii n.* (arguing that "our economic magnanimity toward able-bodied dependents, especially those labeled mentally ill, is ... counterproductive").

${ }^{5}$ Americans with Disabilities Act of 1990, 42 U.S.C. $\$ \S 12101-12213$ (Supp. V 1993). Congress implemented the ADA incrementally. In 1992, the ADA reached only employers with 25 or more employees; the Act took full effect on July 26, 1994, governing any employer with 15 or more employees. See 42 U.S.C. $\$ 12111(5)(A)$; see also infra note 69 (noting that the application of the ADA was effectuated in two stages).

${ }^{6}$ Bonnie Milstein et al., The Americans with Disabilities Act: A Breathtaking Promise for People with Mental Disabilities, 24 CLEARINGHOUSE REv. 1240 (1991). The importance of this legislation is exemplified by the "emotion-filled ceremony" which celebrated its passage. "Let the shameful wall of exclusion finally come tumbling down," stated President Bush as he signed the ADA into law in front of lobbying groups, disabled-persons rights advocates, and "row upon row of disabled Americans cheering and sometimes weeping with happiness." Ann Devroy, In Emotion-Filled Ceremony, Bush Signs Rights Law for America's Disabled, WASH. POST, July 27, 1990, at A18. President Bush went on to describe the ADA as "the world's first comprehensive declaration of equality for people with disabilities." Bush Signs Disabilities Act at White House Ceremony, BNA WASH. INSIDER, July 27, 1990, available in LEXIS, News Library, Arcnws File. Moreover, federal legislators have called the ADA the "Emancipation Proclamation" for disabled persons, see 135 CONG. REC. S4984 (daily ed. May 9, 1989) (statement of Sen. Harkin), and "the most sweeping piece of civil rights legislation since the Civil War era." 135 CONG. REC. 14,198-04 (1989) (statement of Sen. Hatch).

${ }^{7}$ House COMm. ON Educ. ANd Labor, Americans with Disabilities ACT of 1990, H.R. REP. No. 485, 101st Cong., 2d Sess., pt. 2, at 48 (1990) (statement of Sandra (Sandy) S. Parrino, head of the National Council on Disability), reprinted in 1990 U.S.C.C.A.N. 267, 330 [hereinafter HOUSE EDUC. AND LABOR REPORT]. This report is the primary source of legislative history leading up to Title I (the employment provision) of the Americans with Disabilities Act. 
In short, the $\mathrm{ADA}$ guarantees persons with disabilities equal access to societal civil rights. ${ }^{8}$ The Act simultaneously sets up a prohibition against discrimination and an obligation to accommodate reasonably persons with physical and mental impairments. ${ }^{9}$

${ }^{8}$ The ADA protects these rights in five titles: employment (Title I), public transportation and other state and local government services (Title II), public accommodations (Title III), telecommunications (Title IV), and miscellaneous provisions (Title V). This Comment focuses exclusively on Title I. For a more complete and general overview of the Act in its entirety, see THE AMERICANS WITH DisABILITIES ACT: A PRACTICAL AND LEGAL GUIDE TO IMPACT, ENFORCEMENT, AND COMPLIANCE (Bureau of Nat'l Affairs ed., 1990) (reviewing the Act's provisions). The ADA complements the Fair Housing Amendments Act of 1988 ("FHAA"), 42 U.S.C. $\S \S 3602,3604-3631$ (1988), which prohibits discriminatory housing practices based on disability. See GaRY S. MARX \& Gary G. GoldberGer, Disabilrty LAW CoMPLIANCE MANUAL at S8-1 to S8-13 (Cumulative Supp. 1995) (outlining several sections of the FHAA); Bonnie Milstein et al., The Fair Housing Amendments Act of 1988: What It Means for People with Mental Disabilities, 23 CleARINGHOUSE REv. 128, 128-30 (1989) (outlining the purposes of the FHAA).

${ }^{9}$ In discussing mental impairments, it is important to distinguish between the terms "mental disability" and "mental illness," both of which the ADA covers. Although these terms are often used interchangeably to refer to diseases of the mind, in reality they define different mental conditions. This Comment makes every effort not to confuse or conflate these clinical definitions. "Mental disability" refers to neurological impairments due to developmental and organic disorders (for example, cerebral palsy and brain injury). See DebORAH ZUCKERMAN ET AL., ThE ADA AND PEOPLE WITH MENTAL IllNess: A RESOURCE MANUAL FOR EMPLOYERS 1 (1993). By contrast, "mental illness" includes thought, mood, and anxiety disorders (for example, schizophrenia, depressive disorders, paranoias and anxiety disorders, and obsessivecompulsive disorder). See id. at 7. Mental illness is additionally distinguishable by its predominate treatment: the use of psychotropic medication. See id. at 11 . Psychotropic medication, characteristically used to treat the mentally ill, see infra note 47 and accompanying text, is central to this Comment's ultimate proposal.

The Supreme Court has recently acknowledged the distinction between mental retardation and mental illness. See Heller v. Doe, 113 S. Ct. 2637, 2649-50 (1993) (upholding a Kentucky statute which required a higher standard of proof for the involuntary commitment of the mentally ill than for the mentally retarded). In fact, the Court noted that the differentiation between mental illness and mental retardation is a "commonsense distinction ... [that] continues to the present day." Id. at 2646; see also Halderman v. Pennhurst State Sch. \& Hosp., 446 F. Supp. 1295, 1298 (E.D. Pa. 1977), affd in part and rev'd in part, 612 F.2d 84 (3d Cir. 1979), cert. granted, 447 U.S. 904 (1980) (noting that mental "[r]etardation is wholly distinct from mental illness" since it is a learning impairment rather than "a disease which can be cured through drugs or treatment"). These distinctions emphasize the unique nature of mental illness and rely at least in part on the characteristic use of psychotropic medication to treat the mentally ill. See infra part I.B.3 (arguing that mental illness is sufficiently different from other types of disability to warrant additional safeguards against employment discrimination).

In discussing mental illness, courts are guided by the definitions of the AMERICAN

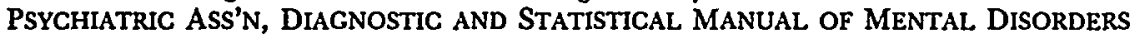
(4th ed. 1994) [hereinafter DSM-IV], a diagnostic reference offered by the American Psychiatric Association ("APA"). See, e.g., Heller, 113 S. Ct. at 2643 (relying on a 
Mental impairments, because of their hidden and often misunderstood nature, present special challenges for the successful implementation of the ADA. In striving toward its goal of inclusion, the ADA faces the difficulty of a long history of exclusion with regard to the mentally impaired..$^{10}$ Furthermore, the ADA's emphasis on physical disability ${ }^{11}$ has led many to construe the Act to provide more direct protection to persons with physical disabilities, suggesting that the Act may be unfairly and unequally applied to persons with mental illness. ${ }^{12}$

previous edition of the Diagnostic and Statistical Manual of Mental Disorders for diagnostic definitions). Legislative history reveals that the drafters of the ADA intended that this APA reference be relied upon in defining mental illness. See 135 CoNG. REc. S11,174 (daily ed. Sept. 14, 1989) ("A private entity that wishes to know what the [ADA] might mean with respect to mental impairments would do well to turn to DSM-III-R [now revised by DSM-IV] ....") (statement of Sen. Armstrong).

This Comment focuses on "mental illness," which is included in the ADA's "mental impairment" category, and is thus considered a disability under the ADA; therefore, mental disabilities, current drug/psychoactive substance use, alcoholism, learning disabilities, and epilepsy fall outside the scope of the present inquiry. For discussions of the ADA's application to these types of disabilities, see generally Reese J. Henderson, Jr., Addiction As Disability: The Protection of Alcoholics and Drug Addicts Under the Americans with Disabilities Act of 1990, 44 VAND. L. REv. 713 (1991); Loretta K. Haggard, Note, Reasonable Accommodation of Individuals with Mental Disabilities and Psychoactive Substance Use Disorders Under Title I of the Americans with Disabilities Act, 43 WASH. U. J. URB. \& CONTEMP. L. 343 (1993).

${ }^{10}$ See Gary B. Melton \& Ellen G. Garrison, Fear, Prejudice, and Neglect: Discrimination Against Mentally Disabled Persons, 42 AM. PSYCHOLOGIST 1007, 1007 (arguing that, historically, the law has provided inadequate protection for the mentally disabled and has even directly discriminated against them); Judith Rabkin, Public Attitudes Toward Mental Illness: A Review of the Literature, ScHIzOPHRENIA BULL., Fall 1974, at 9,19 (recognizing a stigma that prevents the full inclusion of the mentally ill in society and commenting that "[t]oday, as in times past, when people encounter the description or presence of someone who has been labeled mentally ill, they are not pleased to meet him"); Renée Ravid, Disclosure of Mental Illness to Employers: Legal Recourses and Ramifications, 20 J. PsYCHIATRY \& L. 85, 85 (1992) (calling employment discrimination against the mentally ill a "legacy ... of both private and public employers").

$"$ The ADA regulations and the interpretive guidelines issued by the Equal Employment Opportunity Commission ("EEOC"), see infra note 72 and accompanying text, illustrate the provisions of the Act largely with examples of physical disability. For example, the ADA provides disabled persons with the right to auxiliary aids and services. See 42 U.S.C. § 12102(1) (Supp. V 1993). The statute expressly contemplates only the auxiliary needs of the visually and hearing impaired, however, and the EEOC interpretation of this provision leaves it unclear how those with mental impairments might benefit from this right. See Mental and Physical Disabilities Are Treated Differently Under ADA, 12 MENTAL HEALTH L. REP. 33, 33 (1994) [hereinafter Disabilities Treated Differently]; see also Employers Encounter Difficulties in Applying ADA to Mentally Ill, 12 MENTAL HEALTH L. REP. 57, 57 (1994) [hereinafter Employers Encounter Difficulties] (noting that the costs of mental disabilities have been ignored).

${ }^{12}$ See Disabilities Treated Differently, supra note 11, at 33 (noting that "unequal 
This Comment looks at the employment challenges facing the mentally ill under the ADA and argues that the unique nature of mental illness, together with the large success of treatment through medication, warrants additional safeguards for the mentally ill through ADA protection. Part I describes the barriers to employment which face the mentally ill and establishes the unique position of such individuals in the employment setting. Part II introduces the ADA and outlines the mechanics of Title I, the ADA's employment provision. Part III details one ADA employer defense, the direct threat qualification (or "safety defense"), which has broad application to the mentally ill, and evaluates the current interpretations of the defense. Given the unique nature of the mental-illness disability, Part III argues that the safety defense may unfairly be used against persons with mental illness; therefore, additional safeguards are needed to assure that the ADA's protection extends to the mentally ill. Part IV proposes one such safeguard: when an employer attempts to invoke the safety defense against a mentally ill employee, the potentially mitigating impact of psychotropic medication on the illness must be considered. Specifically, this Comment suggests that this safeguard be implemented as an additional factor in the EEOC's current direct threat analysis. This Comment concludes with a discussion of the applications and implications of adding the use of psychotropic medication to the direct threat analysis.

benefit determinations may be due to differing interpretations of mental and physical disabilities"); Stephan Haimowitz, Americans with Disabilities Act of 1990: Its Significance for Persons with Mental Illness, 42 HOSP. \& COMMUNITY PSYCHIATRY 23, 23 (1991) (stating that the "impact of the [A]ct may not be as great" for people with mental illness); infra note 99 (noting that one senator even proposed an amendment that would exclude all persons diagnosed with psychiatric disorders covered by the APA's Diagnostic and Statistical Manual of Mental Disorders from the ADA's protection); see also Louis Pechman, Coping with Mental Disabilities in the Workplace, N.Y. STATE B. J., July-Aug. 1995, at 22, 22 ("Mental disabilities are given equal billing with physical disabilities in the [ADA], but you wouldn't know that by looking at the ADA's legislative history."). For instance, during one floor debate on the ADA, a senator remarked:

While the committee report gives examples of clear-cut accommodations for the [physically] disabled, it studiously avoids the more bizarre accommodation requirements imposed by the bill. What are employers expected to do to accommodate alcoholics, the mentally retarded, or persons with neurotic or psychotic disorders? This Senator has no idea, and I doubt that other Senators do either.

135 CoNG. REC. S10,783 (daily ed. Sept. 8, 1989) (statement of Sen. Humphrey). 


\section{MENTAL ILLNESS AND EMPLOYMENT}

\section{A. Mental Illness As a Barrier to Employment}

Today, it is estimated that 1.5 million Americans have some form of severe, persistent, disabling mental illness that interferes with daily functioning. ${ }^{13}$ Moreover, up to twenty percent of the U.S. population suffers from a diagnosable psychiatric disorder. ${ }^{14}$ Depressive disorders, ${ }^{15}$ anxiety disorders, ${ }^{16}$ and schizophrenia ${ }^{17}$ are

${ }^{19}$ See Janet O'Keeffe, Disability, Discrimination, and the Americans with Disabilities Act, in IMPLICATIONS OF THE AMERICANS WITH DISABILITIES ACT FOR PSYCHOLOGY 1, 2 (Susanne M. Bruyère \& Janet O'Keeffe eds., 1994).

14 See David A. Larson, Mental Impairments and the Rehabilitation Act of 1973, 48 LA. L. REV. 841, 846 (1988).

${ }^{15}$ Depressive disorders are characterized by periods of sadness and intense grief severe enough to affect daily functioning. See ZUCKERMAN ET AL., supra note 9, at 64 . Four common diagnoses include major (unipolar) depression, manic-depressive (bipolar) disorder, dysthymia, and seasonal affective disorder. See id. Symptoms of depressive disorders include feelings of worthlessness or helplessness, persistent and intense sadness, pessimism, social withdrawal, inappropriate guilt, recurrent thoughts of suicide, marked personality change, problems with sleeping or excessive fatigue, irregular eating patterns, difficulty concentrating, restlessness, and anger out of proportion to the situation. See id. at 64-65. Bipolar disorder differs from the other three in that the individual experiences manic episodes ("highs") in addition to depression ("lows"). See id. at 65 . Just as depression is more than a bad mood, these manic episodes are not simply a good mood or a break in the depression. See id. Rather, mania is a euphoric state which may lead the individual to experience rushes of ideas or thoughts, grandiose notions, extreme distractibility, abundant energy, increased risk-taking, rapid talking or fidgeting, and a tendency to act irrationally and to overlook harmful or painful consequences of behavior. See id. For clinical definitions of these disorders, see DSM-IV, supra note 9.

${ }^{16}$ Examples of anxiety disorders are phobias, panic disorder, obsessive-compulsive disorder ("OCD"), and post-traumatic stress disorder. See ZUCKERMAN ET AL., supra note 9 , at 60 . Phobia, the most common anxiety disorder, is an irrational, persistent, and excessive fear in response to an object or situation. See id. Social phobia (fear of situations that expose a person to another's judgment) and agoraphobia (fear of being in situations from which escape might be embarrassing or difficult) present serious ramifications in the workplace. See id. at 60-61. OCD, characterized by compulsions and obsessions (that is, repeated washing of hands) consumes significant time and energy in one's day and interferes with one's daily schedule. See id. at 62. Anxiety disorders result in symptoms such as panic attacks, cardiac distress, difficulty breathing, loss of bladder control, paralyzing fear, nausea, or intrusive thoughts or impulses. See id. at 60-63. For clinical definitions of these disorders, see DSM-IV, supra note 9. For a discussion of the ADA's treatment of phobias, see John M. Casey, Comment, From Agoraphobia to Xenophobia: Phobias and Other Anxiety Disorders Under the Americans with Disabilities Act, 17 U. PUGET Sound L. REV. 381 (1994).

${ }^{17}$ Schizophrenia is a highly complex disorder resulting in disassociation or fragmentation of ideas that leads to delusions, hallucinations, notions of grandeur, and thought disorders. See ZUCKERMAN ET AL., supra note 9, at 66-67. These manifestations contribute to social withdrawal or isolation, inability to communicate 
the most prevalent forms of mental illness. ${ }^{18}$ In addition to these specific afflictions, persons with mental illness suffer from low selfesteem, feelings of inadequacy, social anxiety, stigma, and selfblame. ${ }^{19}$

These statistics carry broad implications for America's workforce. As the first symptoms of mental illness frequently surface between the ages of fifteen and twenty-five-years generally reserved for substantial educational and/or vocational training ${ }^{20}$-the unemployment rate for the mentally ill has been measured to be as high as seventy percent. ${ }^{21}$ Although each mentally ill individual faces unique challenges, the common difficulties faced by the mentally ill in the workplace include: functional difficulties, problems socializing, limited stamina, irregular attendance, maladaptive coping mechanisms for stress, heightened anxiety, difficulty accepting feedback, distractibility, fear of relapse, stress due to fear of stigma resulting from disclosure of the illness, physical side effects of medication, ${ }^{22}$ and an inability to respond to change. ${ }^{23}$

with others, impairment in personal hygiene and grooming, and inappropriate affect. See id. at 67 . Schizophrenia should not be confused with multiple personality disorder, which is a wholly separate and rare disorder. See id. at 66 . For clinical definitions of schizophrenia, see DSM-IV, supra note 9.

${ }^{18}$ See ZUCKERMAN ET AL., supra note 9, at 9. Fifteen percent of all persons suffer from some form of severe depression during their lifetime. See Larson, supra note 14, at 846. Six percent will experience major depression. See ZuCKERMAN ET AL., supra note 9, at 64 . Five to ten percent suffer an affective disorder, and five to ten percent are afflicted with severe personality disorder; more than five percent develop generalized anxiety. See Larson, supra note 14, at 846 . Nearly two percent of adults have schizophrenia. See ZUCKERMAN ET AL., supra note 9, at 66. Moreover, mental illness frequently accompanies substance abuse. See id. at 13-14 (referring to a National Institute of Mental Health study that found that $30 \%$ of mentally ill adults have also had a diagnosable drug and/or alcohol abuse disorder and that $53 \%$ of aduits with a substance abuse disorder have had at least one mental illness).

${ }^{19}$ See Adrienne Asch, The Experience of a Disability: A Challenge for Psychology, 39 AM. PSYCHOLOGIST 529, 531-32 (1984) (suggesting that handicaps "arouse anxiety" in both handicapped and non-handicapped people).

${ }^{20}$ See ZUCKERMAN ET AL., supra note 9, at 8 (asserting that mental illness may well result in individuals missing "substantial portions of traditional educational or vocational training").

${ }^{21}$ See H. Keith Massel et al., Evaluating the Capacity to Work of the Mentally Ill, 53 PsYCHIATRY 31, 31 (1990); see also E. Sally Rogers et al., Psychiatric Rehabilitation As the Preferred Response to the Needs of Individuals with Severe Psychiatric Disability, 33 REHABILITATION PSYCHOL. 5, 8 (1988) (estimating that "no more than $20 \%$ to $30 \%$ of individuals with psychiatric disability are competitively employed").

${ }^{22}$ See infra notes 159-62 and accompanying text (discussing the side effects of medication).

${ }^{23}$ See ZuCKERMAN ET AL., supra note 9, at 12-13 (considering each of these difficulties in turn); see also Carroll M. Brodsky, Factors Influencing Work-Related 
These problems are magnified by the fact that the mentally ill are considered potentially dangerous in the workplace, and indeed in many other contexts as well. ${ }^{24}$ The inherently subjective nature of mental illness adds to the difficulty of distinguishing misperceptions from reality in the workplace. ${ }^{25}$ Despite empirical evidence that mental illness is not a predictor of violence, ${ }^{26}$ the media-driven image of the dangerous lunatic persists. ${ }^{27}$ This image, combined with a presumption of incompetence, has prompted a generally skeptical attitude toward hiring the mentally ill. ${ }^{28}$

Disability, in Psychiatric DISABILITY: Clinical, LeGal, AND ADMINISTRATIVE DIMENSIONS 49, 52-57 (Arthur T. Meyerson \& Theodora Fine eds., 1987) (describing some of these difficulties in detail).

${ }^{24}$ See SZASZ, supra note 3, at xii (recognizing the common assumption that persons who "are mentally ill . . . are a danger to themselves and others"). Szasz continues:

Bedlam is now everywhere, making our streets and parks both ugly and unsafe. Ugly because we tolerate unacceptable behavior by persons so long as, de jure, they are classified as mental patients; and unsafe because many of these individuals engage in de facto aggression, depriving others of property, liberty, and even life.

Id. at 168.

${ }^{25}$ See Equal EMPLOYMENT OpPoRTUNity COMM'N, A TeChNiCAl Assistance Manual of the Employment Provisions (TITLE I) OF THE AMERICANS WITH DisABILITIES ACT at III-2 (Jan. 1992) [hereinafter EEOC, TECHNICAL AsSISTANCE MANUAL] (noting that "[m]any [persons with disabilities] are excluded [from the workplace] only by barriers in other people's minds; these include unfounded fears, stereotypes, presumptions, and misconceptions about job performance, safety, absenteeism, costs, or acceptance by coworkers and customers").

${ }^{26}$ Although "future violence by a mental patient cannot be reliably predicted," the dangerousness of the mentally ill, to themselves or others, is typically overpredicted. Elio Maggio, The Psychiatry-Law Dilemma: Mental Health Versus Human RIGHTS 18 (1981). In fact, studies have indicated that a person with a mental illness may actually be less dangerous than a member of the normal population. See id.; see also ZUCKERMAN ET AL., supra note 9, at 9 (stating that "most people with mental illness are neither dangerous nor unpredictable"). The studies indicating that the mentally ill are less violent than the "normal" population, however, were made at a time when "prolonged hospitalization . . . may have prevented investigations from detecting violent behavior." MAGGIO, supra, at 18. More recent studies, made at a time when the mentally ill were being deinstitutionalized, have found that "the psychiatric patient is, indeed, more prone to violence than the normal individual." Id. at 19. It is not established, however, whether these conclusions may be generalized to include noninstitutionalized, mainstream mentally ill who are functioning well in society.

${ }^{27}$ See ZUCKERMAN ET AL., supra note 9, at 9.

${ }^{28}$ Common myths and misconceptions held by employers include the beliefs that the turnover rate for disabled employees is high, that accommodations for disabled persons are unduly expensive, that disabled individuals do not contribute to productivity in the workplace, and that the presence of disabled employees makes customers and clients feel uncomfortable. See Peter D. Blanck, The Emerging Work 
Historically, mental impairment was seen as symbolic punishment for moral transgressions: ${ }^{29}$ " $[\mathrm{M}]$ ental illness has been historically associated with sin, evil, God's punishment, crime, and demons." ${ }^{30}$ Even legal study reveals a history tainted with labels and characterized by intolerance and disdain for the mentally ill. $^{31}$ The result is that the mentally ill, perceived as prisoners of their own deficient minds, have been lowered to the level of "third-class citizens" by the presumption that they are dependent and incompetent. ${ }^{32}$ Mental illness is still greeted with skepticism by many, and the concept of coupling mental illness with independence remains unthinkable. ${ }^{33}$ "Today, people find it intolerable to witness a person talking to himself, depressed, contemplating suicide. The public wants to be spared this spectacle. ${ }^{n 34}$ It is faced with these deeply rooted perceptions, and at the risk of creating a "spectacle," that the mentally ill enter the employment market.

\section{B. Mental Illness As Distinct from Other Disabilities}

\section{Mental Illness Differs from Physical Disability}

Given the unique nature of the disability, it is not surprising that mental illness presents special challenges in the workplace. Its main counterpart, physical disability, may be distinguished on several grounds. First, unlike physical disability, which is typically apparent, mental illness is a disease hidden in the mind. Because mental illnesses "are far more complex and elusive" than physical

Force: Empirical Study of the Americans with Disabilities Act, 16 J. CORP. L. 693, 698 (1991) (summarizing ten common false myths and misconceptions held by employers of disabled persons).

${ }^{29}$ See O'Keeffe, supra note 13, at 4. The historical perception of mental illness as demonic in origin dates back to biblical times. See ROTH \& KROLL, supra note 4, at 33-34 (discussing the portrayal of madness in the Old Testament and citing 1 Samuel 21:10-16).

${ }^{\text {so }}$ Pechman, supra note 12, at 26.

${ }^{\text {s1 }}$ Cf. Buck v. Bell, 274 U.S. 200, 207 (1927) (upholding a Virginia law that provided for the sterilization of the feebleminded since "[t]hree generations of imbeciles are enough").

${ }^{32}$ See Margaret A. Nosek, The Americans with Disabilities Act of 1990-Will It Work? (Con), 46 AM. J. OCCUPATIONAL ThERAPY 466, 466 (1992) ("[B]y itself, the ADA is powerless to resolve the innumerable barriers that have kept people with disabilities as third-class citizens for millennia.").

${ }^{33}$ See SzASZ, supra note 3, at 192 ("Freedom does not cure cancer or heart disease. Why, then, should we expect it to cure mental illness?").

${ }^{34} I d$. at 61. 
disabilities, employers are less likely to recognize an employee with mental illness on sight. ${ }^{35}$ Moreover, while a physical disability may have an overt manifestation, such as paraplegia, a mental illness rarely does. ${ }^{36}$ Often mental illness is "hidden," or not readily apparent upon sight. ${ }^{37}$ This overt/covert distinction also justifies differentiating mental illness from other types of mental impairments that do manifest themselves physically, such as mental retardation. ${ }^{38}$

Second, mental illness is harder to understand than physical disability due to a lack of medical knowledge among professionals and a lack of familiarity among laypersons. Thus, with respect to mental illness, the law has evolved into an interactive exchange among mental health specialists. ${ }^{39}$ Physical disabilities are "easier" to deal with; they are more likely to have an agreed-upon course of treatment and expected recovery time, whereas diagnoses of mental illnesses are far less certain. ${ }^{40}$

${ }^{35}$ Pechman, supra note 12, at 22. Of course, to some extent, even "pure" mental illnesses present some psychosomatic manifestations. See ROTH \& KROLL, supra note 4 , at 27 (using depression to illustrate "the inseparability of physical and emotional components" of mental illness).

${ }^{36}$ See Pechman, supra note 12, at 22 (stating that mental illness "does not reside in a single organ or system").

${ }^{37}$ See ZUCKERMAN ET AL., supra note 9, at 22.

${ }^{3 s}$ See supra note 9 (distinguishing mental illness from mental disability and noting that the scope of this Comment only extends to the former); infra part I.B.3 (discussing the Supreme Court's treatment of this distinction in Heller v. Doe, 113 S. Ct. 2637 (1993)).

${ }^{39}$ See Adrienne L. Hiegel, Note, Sexual Exclusions: The Americans with Disabilities Act As a Moral Code, 94 Colum. L. REv. 1451, 1458 (1994) (tracing the law's role in defining disability and noting that " $[\mathrm{d}]$ iagnoses of capacity and mental illness are now routinely made by lawyers in courtroom hearings as the roles of legal actor and professional medical expert have become less and less clearly defined"). In mental health law, the relevant experts include psychiatrists, psychologists, and psychoanalysts; each of these professionals has a distinct role in determining the causes and treatments of mental illnesses. For a concise description of the roles of these specialists, see Stephen J. Morse, Crazy Behavior, Morals, and Science: An Analysis of Mental Health Law, 51 S. CAL. L. REv. 527, 533 n.12 (1978); see also ZUCKERMAN ET AL., supra note 9, at 71 (describing sources of professional help within mental health services). These experts are relevant to our present inquiry because lawyers pay them considerable deference in mental health law issues. See Morse, supra, at 536. Similarly, it behooves the legal scholar to consult mental health experts in interpreting the ADA as it applies to persons with mental illnesses. See O'Keeffe, supra note 13 , at 10 (discussing the significance of the ADA for health care specialists).

${ }^{40}$ See Pechman, supra note 12, at 22 (comparing a slipped disc to schizophrenia and noting that the latter is more difficult to diagnose, has an uncertain period of recovery, and presents conflicting courses of action for treatment). Moreover, the 
Third, the hidden and misunderstood nature of mental illness contributes to suspicion and disbelief that does not exist for physical disabilities. Lurking behind a diagnosis is the "myth of mental illness." ${ }^{41}$ A person disabled with anxiety disorder, for example, simply does not have the same kind of hard evidence of disability as does one who is confined to a wheelchair. While those with physical disabilities are viewed as unfortunate victims, those with mental illnesses must contend with the presumption that the disability is somehow their fault. ${ }^{42}$

Finally, mental illness evokes a different response than physical disability among the public. While one might feel pity for the physically disabled, fear is a more common response to the mentally ill, as noted in a 1991 Harris Poll. ${ }^{43}$ This study of public attitudes toward persons with disabilities indicated that while contact with physically disabled persons generally evoked pity and embarrassment, ${ }^{44}$ contact with the mentally ill engendered significant apprehension. ${ }^{45}$ Indeed, "characterizing a particular problem as

definitions and diagnoses of mental illness are constantly changing. See infra note 144 and accompanying text (arguing that the exercise of reasonable medical judgment is inherently difficult with mental illness).

${ }^{11}$ Thomas S. SZASZ, The MYTH OF MENTAL Illness (1974). Indeed, Szasz rejects altogether the concept of mental illness, attributing the condition to a societal metaphor. See id. at x; see also ThOMAS S. SzASz, THE MANufacture OF MADNESS at xix (1970) (analogizing the modern conception of mental illness to the medieval belief in witchcraft).

12 Szasz states that

[a]lthough a person may behave abnormally because he has a brain disease, the typical madman behaves the way he does because of his particular adaptation to the events that make up his life. Examples abound in Shakespeare's tragedies. King Lear goes mad because of his poor choice for retirement. Lady Macbeth is driven mad by guilt and remorse over a criminal career. Hamlet breaks down under the stress of discovering that his mother and uncle murdered his father.

SzASZ, supra note 3, at 109 (emphasis added); see also id. at 118-20 (discussing the link between mental illness and personal responsibility in Shakespeare's work).

43 The Harris Poll, commissioned by the National Organization on Disability (NOD), is conducted by interviewing adults (ages 18 and older) from across the nation via telephone. See NATIONAL ORG. ON DISABILITY, PUBLIC ATTITUDES TOWARD PEOPLE WITH DISABILITIES 70 (1991). The 1991 Harris Poll reflects views from 1257 telephone interviews. See id. at 81 .

11 The results of the Harris Poll indicate that upon encountering persons with severe physical disabilities, $92 \%$ of those surveyed feel admiration, $74 \%$ experience pity, and 58\% feel embarrassed or awkward. See id. at 13. Moreover, 30\% indicate that they would be concerned about working closely with a severely disabled coworker, and $23 \%$ would be uncomfortable with a boss who was seriously disabled. See id. at 15.

${ }^{45}$ See id. at 18 (reporting that only $19 \%$ of those surveyed reported being 
a mental disease may lead to greater stigmatization than would some other way of describing the difficulty. ${ }^{46}$

\section{Mental Illness Involves Unique Treatment}

Mental illness is not only distinguishable from other types of disability on the basis of its manifestations, but also on the basis of its treatment-the use of psychotropic medication. ${ }^{47}$ Such medication is widely successful in treating the symptoms of mental illness because it can control the biochemical imbalances in the body and brain which researchers now believe cause many mental illnesses. ${ }^{48}$ For the most common mental illnesses, ${ }^{49}$ psychotropic medication can be divided into four categories: ${ }^{50}$ antidepressants (to treat depressive disorders), ${ }^{51}$ antimanics (to treat bipolar disorder or

comfortable around the mentally ill); see also Blanck, supra note 28, at 794 (reviewing the findings of the 1991 Harris Poll and noting that mental illnesses evoke particular uneasiness).

${ }^{46}$ Alexander D. Brooks, Law, Psychiatry and the Mental Health System 64 (1974).

${ }^{17}$ Psychotropic medication refers to drugs used in the treatment of mental illness. See ZUCKERMAN ET AL., supra note 9, at 72. Of course, there are other valid, and often superior, treatment options for mental illness aside from psychotropic medication. Among other reasons, the side effects that typically accompany the use of medication may lead an individual to nonchemical types of therapy. See id. at 69. Several types of psychotherapy are available such as individual therapy, group therapy, or family therapy. See id. at 69-70. Different approaches to therapy exist as well, including cognitive therapy (focusing on thought processes), behavioral therapy (working to establish adaptive habits), interpersonal therapy (focusing on developing relationships with others), psychosocial therapy (developing social and vocational skills), and psychodynamic therapy (focusing on conflicts in the unconscious). See id. In addition, therapy may be used in conjunction with psychotropic medication. See $i d$. at 67 . For a number of reasons, this Comment specifically addresses the treatment of the mentally ill through the use of psychotropic medication. First mental illness is characterized by the predominance of treatment by medication. See infra note 61 and accompanying text. Second, the side effects of medication present potential problems in the workplace that are not presented by therapy. See ZUCKERMAN ET AL., supra note 9, at 68-69. Finally, therapy is easily accommodated by the employer, and attendance at therapy may not be as potentially threatening to employers as is the employee's use of medication. See id. at 35 (noting that "many accommodations for persons with mental illness simply require observation, flexibility and the application of good management techniques").

${ }^{48}$ See ZUCKERMAN ET AL., supra note 9, at 68.

${ }^{49}$ See supra notes $15-17$ and accompanying text.

${ }^{50}$ See ZUCKERMAN ET AL., supra note 9, at 68-69.

${ }^{51}$ Antidepressants control the level of neurotransmitters in the brain and include such medications as tricyclics, monoamine oxidase inhibitors (MAOIs), and serotonin re-uptake inhibitors. The common side effects include drowsiness, dizziness, dry mouth, blurred vision, nausea, and headaches. See id. at 68 . 
manic-depressive disorder), ${ }^{52}$ antianxiety medication (to treat anxiety disorders), ${ }^{53}$ and antipsychotics (to treat schizophrenia). ${ }^{54}$

\section{Mental Illness Has Received Special Supreme Court Consideration on the Basis of Its Unique Manifestations and Treatment}

Although the Supreme Court has never explicitly held that the mentally ill deserve special protection, ${ }^{55}$ the Court has recently

52 The most common form of antimanic is lithium carbonate. Lithium seeks to level the mood swings among those suffering from manic-depressive disorder. Because fatigue, cramps, and severe thirst commonly accompany the use of lithium, additional medication may be prescribed to combat the drug's side effects. See id. at 68-69.

${ }^{53}$ The principal subtype of antianxiety medications is benzodiazepine, which relaxes the individual. This calming effect, however, may cause such side effects as slurred speech, confusion, fatigue, and breathing difficulties. Antidepressants may also be prescribed for some anxiety disorders. See id.

${ }^{5 t}$ Antipsychotic medications seek to eliminate the symptoms of schizophrenia, such as hallucinations and delusions, and to help the individual identify "the real world." Common types include phenothiazines, butyrophenones, and thioxanthenes. In addition to the side effects experienced through other psychotropic medications, such as dry mouth, blurred vision, and rapid heartbeat, $15 \%$ to $20 \%$ of those treated with antipsychotics experience tardive dyskinesia (TD). TD is a condition characterized by spasms of the mouth, specifically involuntary movements of the lips and tongue. See id. at 69 .

${ }^{55}$ Cf. Melton \& Garrison, supra note 10, at 1008 (discussing the stigmatization and "lengthy history of invidious discrimination against" the mentally disabled). This article criticized the landmark Supreme Court case, City of Cleburne v. Cleburne Living Ctr., 473 U.S. 432 (1985), in which the Court refused to extend quasi-suspect classification, and thus heightened scrutiny, to the mentally retarded. In Cleburne, the Court struck down an ordinance that required a special use permit for the operation of a group home for the mentally retarded because it was not rationally related to any legitimate state purpose. See id. at 450 . While this decision illustrates the Court's reluctance to expand the definition of quasi-suspect class, the Fair Housing Amendments Act of 1988 may be regarded as a response to Clebume. See Robert L. Schonfeld \& Seth P. Stein, Fighting Municipal "Tag-Team": The Federal Fair Housing Amendments Act and Its Use in Obtaining Access to Housing for Persons with Disabilities, 21 FORDHAM URB. L.J. 299, 303 n.20 (1994) (noting that the FHAA would prohibit the Cleburne ordinance). The Court has not yet addressed whether the mentally ill should be considered a quasi-suspect class; however, the Court recently refused to reconsider extending heightened scrutiny to the mentally retarded. See Heller v. Doe, 113 S. Ct. 2637, 2650 n.l (1993) (Souter, J., dissenting) (discussing the respondent's argument that the mentally retarded are a discrete and insular minority for whom heightened scrutiny is mandated).

In light of Cleburne, it seemed unlikely that the Court would extend this protected status to the mentally ill; to the extent that mental illness is not immutable, but rather is treatable, mental illness seems an even less likely candidate for heightened scrutiny than mental retardation. Nonetheless, the Court's recent decision in Heller suggests that the mentally ill may deserve special protection. The 
legitimized their unique status in Heller v. Doe. ${ }^{56}$ Highlighting the risk of erroneous diagnosis with respect to the mentally ill, the Court compared mental illness to mental retardation and upheld a state statute that distinguished between the two disabilities in involuntary commitment proceedings. ${ }^{57}$ First, the Court noted the difficulty inherent in diagnosing mental illness because the onset of the disability is sudden and may not occur until adulthood..$^{58} \mathrm{By}$ virtue of its physical manifestation, mental retardation, according to the Court, is easier to identify. ${ }^{59}$ Second, in discussing predictions of dangerousness, the Court noted that while mental retardation is a static, predictable condition, " $[t]$ his is not so with the mentally ill. Manifestations of mental illness may be sudden .... It is thus no surprise that psychiatric predictions of future violent behavior by the mentally ill are inaccurate. ${ }^{260}$

Perhaps the most forceful distinction between the mentally retarded and the mentally ill, however, was drawn between the prevailing treatment methods. The mentally ill, the Court noted, are subject to more intrusive treatments, ranging from thought inquiries to psychotropic drug intake. ${ }^{61}$

Court acknowledged the unique challenges of the mentally ill and concluded that legislatures may statutorily acknowledge this distinction. See id. at 2643-49 (endorsing a Kentucky statute that provided a higher burden of proof for involuntary commitment on the basis of mental illness).

Unlike the FHAA, which responded with retroactive protection, the ADA takes a proactive approach in protecting the mentally ill by declaring that "individuals with disabilities are a discrete and insular minority," thus deserving of protection against the menace of discrimination. 42 U.S.C. $\$ 12101$ (a)(7) (Supp. V 1993) (borrowing from United States v. Carolene Prods. Co., 304 U.S. 144, 152 n.4 (1938) ("Prejudice against discrete and insular minorities ... may call for a correspondingly more searching judicial inquiry.")).

${ }^{56} 113$ S. Ct. 2637 (1993).

${ }^{57}$ See id. at 2643-47.

${ }^{58}$ See id. at 2644 (citing Addington v. Texas, 441 U.S. 418, 430 (1979)).

${ }^{59}$ See id. (comparing mental retardation with depression and schizophrenia); $i d$. at 2647 (noting that even experts in the mental health field face "severe difficulties inherent in psychiatric diagnosis" of mental illnesses).

${ }^{60} \mathrm{Id}$. at 2644 . The challenged statute required a dangerousness determination as a prerequisite to commitment. See id. at 2641 . The assessment asked whether the individual presented "a danger or a threat of danger to self, family, or others." Id. The Court's concern that assessments of dangerousness with respect to the mentally ill carry a great risk of error is especially significant to this Comment, given the recent EEOC standard that allows an employer to defend an ADA claim on the basis that the employee presents a risk of safety to herself or others. See infra part III.B (discussing the EEOC's risk-to-self-or-others standard for the ADA safety defense).

${ }^{61}$ See Heller, 113 S. Ct. at 2645 . By contrast, treatment of the mentally retarded 
Thus, the Supreme Court supports the notion that the mentally ill suffer from a condition sufficiently different from other disabilities to warrant special consideration. Recall also that in Heller $v$. Doe, the Court distinguished mental illness from mental retardation, which is a disability presenting both mental and physical manifestations. The Court's arguments identifying "a commonsense distinction between the mentally retarded and the mentally ill [that] continues to present day ${ }^{\mathbf{n} 2}$ would seem to apply with even greater force when comparing mental illness to purely physical disabilities.

The mentally ill individual's struggle for employment differs from that of other disabled individuals by virtue of the special challenges presented by mental illness. The workplace becomes a bittersweet place in which the mentally ill person strives to achieve societal integration only to be confronted with the reality of discrimination. It has been left to Congress to eradicate stigmatizing actions and attitudes; the ADA represents the most recent and comprehensive congressional effort to eliminate discrimination against the disabled in the workplace.

\section{THE ADA}

\section{A. General Application}

"The purpose of the $[\mathrm{ADA}] \ldots$ is to provide a clear and comprehensive national mandate to end discrimination against individuals with disabilities and to bring persons with disabilities into the economic and social mainstream of American life

does not typically include the use of psychotropic medication, but instead focuses on "habilitation," such as "self-care and self-sufficiency skills." Id. (citing Youngberg v. Romeo, 457 U.S. 307, 309 (1982)).

${ }^{62} \mathrm{Id}$. at 2646. The Court's decision in Heller v. Doe, which upheld as rational Kentucky's use of a burden of proof for the involuntary commitment of the mentally ill that was higher than that required for the commitment of the mentally retarded, is, of course, not without criticism. Justice Souter, joined by Justices Brennan and Stevens and by Justice O'Connor in part, wrote a scathing dissent. See id. at 2650-58. Among his criticisms, Justice Souter noted that psychotropic medications also have application to the mentally retarded. See id. at 2655 (stating that $73 \%$ of the committed mentally retarded are treated with psychotropics). While this case presents several compelling mental health issues in the context of involuntary commitment, the application of Heller to this Comment is limited to the Court's comparison of mental illness to other types of disabilities. For interesting commentaries examining Heller, see Heidi A. Boyden, Heller v. Doe: Denying Equal Protection to the Mentally Retarded, 21 NEw ENG. J. ON CRIM. \& Crv. ConfinemenT 437 (1995) and Mari-Rae Sopper, Heller v. Doe: Involuntayy Commitment Under a Reasonable Doubt, 72 DENV. U. L. REV. 491 (1995). 
"63 Recognizing that an estimated forty-three million persons in the United States suffer from some type of disability, the ADA expands the Rehabilitation Act of $1973^{64}$ to protect America's largest minority group from discrimination. ${ }^{65}$ It is with these challenges in mind that the ADA strives to eliminate discriminatory employment practices in what might be the most crucial legislation ever enacted for disabled persons. ${ }^{66}$ Title $I$, the most important section of the $\mathrm{ADA},{ }^{67}$ represents the most recent comprehensive civil rights legislation protecting disabled employees. The importance of Title I stems from the fact that approximately two-thirds of working-age persons with disabilities are unemployed. ${ }^{68}$

The provisions of Title I apply to employers with more than fifteen employees. ${ }^{69}$ In simplest terms, the ADA prohibits employers from discriminating against persons with physical or mental impairments who are otherwise qualified, with or without reasonable accommodation, to perform the essential functions required by a particular job. As a defense to a charge of discrimination, the employer may prove that accommodating the disability would inflict

${ }^{63}$ HOUSE EDUC. AND LABOR REPORT, supra note 7, at 22.

6429 U.S.C. $\$ \S 701-797$ (1988 \& Supp. V 1993). The drafters modeled the ADA upon the Rehabilitation Act as well as other prior civil rights laws. See HOUSE EDUC. AND LABOR REPORT, supra note 7, at 55. Indeed, the ADA seeks to fill the gaps left by prior law and, to that end, is an expansion of coverage. See Wendy E. Parmet, Discrimination and Disability: The Challenges of the ADA, 18 LAW MED. \& HEALTH CARE 331, 331 (1990). Case law interpreting the Rehabilitation Act, because it is the predecessor statute to the ADA, is instructive. Although the cases that emerged under the Rehabilitation Act lack binding precedential value when applied to the $\mathrm{ADA}$, their authority remains very persuasive in shaping judicial interpretation. See infra notes 74, 87 and accompanying text (discussing the relationship between the Rehabilitation Act and the ADA).

${ }^{65}$ See 42 U.S.C. $\$ 12101(a)(1)$ (Supp. V 1993) (ADA Statement of Findings).

${ }^{66}$ See O'Keeffe, supra note 13 , at 1 .

${ }^{67}$ See Parry, supra note 1, at 525 (calling Title I the "single most important title, since employment is the key to independence"); Debra Rybski, A Quality Implementation of Title I of the Americans with Disabilities Act of 1990, 46 AM. J. OCCuPATIONAL THERAPY 409, 409 (1992) ("Many proponents of the law believe that Title I may be the most important provision.").

${ }^{68}$ See 42 U.S.C. \$ 12101(a) (ADA Statement of Findings) (noting the importance Congress placed upon Title I); see also H.R. REP. No. 485, 101st Cong., 2d Sess., pt. 2 , at 32 (1990) (noting that $66 \%$ of disabled working-age people are unemployed and desire employment); ZUCKERMAN ET AL., supra note 9, at 15 (same).

69 The ADA was implemented in two phases over four years. Title I applied to employers with more than 25 employees as of July 26, 1992, and extended coverage to employers with more than 15 employees on July 26, 1994. See 42 U.S.C. $\S 12111(5)$ (A) (Supp. V 1993). 
undue hardship on the business ${ }^{70}$ or that the disabled employee poses a direct threat to health or safety in the workplace. ${ }^{71}$ The ADA bestows the interpretive responsibility of Title I upon the EEOC. $^{72}$

\section{B. Stating a Claim Under the ADA-The Requirements}

The ADA is a string of statutory buzzwords that require careful interpretation to effectuate the Act's goals. Paraphrased, the ADA protects from employment discrimination persons with disabilities who, with or without reasonable accommodation, are otherwise qualified to perform the essential functions of the position they are seeking. ${ }^{73}$ The next part of this Comment analyzes these prerequisites for ADA protection.

\section{A "Disability"}

The ADA invokes three possible definitions of "disability":

The term "disability" means, with respect to an individual-

(A) a physical or mental impairment that substantially limits one or more of the major life activities of such individual; or

(B) a record of such an impairment; or

(C) being regarded as having such an impairment. ${ }^{74}$

${ }^{70}$ See 42 U.S.C. $\$ 12111(10)$.

${ }^{71}$ See 42 U.S.C. $\$ 12113($ b); infra part III.A. The ADA literature has shortened the "direct threat to safety defense" (or "direct threat qualification") to its nickname, the "safety defense." See Bryan P. Neal, The Proper Standard for Risk of Future Injury Under the Americans with Disabilities Act: Risk to Self or Risk to Others, 46 SMU L. REv. 483, 484 (1992).

${ }^{72}$ See 42 U.S.C. $\$ 12111(1)$.

${ }^{73}$ See infra note 100.

742 U.S.C. \$ 12102(2) (Supp. V 1993); cf. Rehabilitation Act of 1973, 29 U.S.C. $\S 794$ (1988 \& Supp. V 1993) (defining the scope of the Rehabilitation Act). That the ADA uses the term "disabled" reflects the deliberate abandonment of the label "handicapped" used in the statutory language of the Rehabilitation Act. Nevertheless, the ADA's coverage of "disability" is only marginally different from that of "handicap" under the Rehabilitation Act due to the nearly identical definitions of the terms. See Kathleen D. Henry, Civil Rights and the Disabled: A Comparison of the Rehabilitation Act of 1973 and the Americans with Disabilities Act of 1990 in the Employment Setting, 54 ALB. L. REV. 123, 127-28 (1989) (noting that the acts share similar statutory language and that the ADA expands the scope of covered employers); see also Chai R. Feldblum, The Americans with Disabilities Act Definition of Disability, 7 LAB. LAw. 11, 12-13 (1991) (briefly describing the evolution of the ADA definition of disability and its relationship to the Rehabilitation Act); supra note 64 (noting that the Rehabilitation Act is the predecessor statute to the ADA); infra note 87 (same). 
Satisfying any one of the three parts will suffice to show a "disability" under the ADA. The following subsections evaluate each one of these possibilities in turn.

\section{a. "Substantially Limiting" Impairment}

The first definition includes diagnosable disorders; for mental impairments, this definition includes most disorders defined by the American Psychiatric Association in the DSM-IV. ${ }^{75}$ The statute makes no attempt to enumerate the covered disabilities due to the continuous discovery of new disorders and the impossibility of comprehensiveness. ${ }^{76}$ Furthermore, this first prong does not cover simple physical characteristics (for example, eye color), simple personality characteristics (for example, bad temper), or economic, environmental, or cultural circumstances (for example, age and prison record). ${ }^{77}$ Even if a person has a qualifying impairment, that alone is not enough to invoke the protection of the ADA; the disability must also "substantially limit a major life function," which includes walking, breathing, caring for oneself, speaking, seeing, hearing, learning, working, or engaging in community activities. ${ }^{79}$

\section{b. A "Record of Impairment"}

The second definition, requiring a "record of impairment," exists to protect persons with a history of disability (whether or not they are currently disabled) and also those persons who have been misdiagnosed. The EEOC guidelines explicitly state that this prong is intended to protect persons with a history of mental

' ${ }^{75}$ See supra note 9 (discussing the drafters' intent to give the DSM-IV an authoritative role in defining mental impairments for the purposes of the ADA); see also infra text accompanying note 99 (enumerating the exclusions to the category of qualified impairments).

${ }^{76}$ See HOUSE EDUC. AND LABOR REPORT, supra note 7, at 51 (noting the difficulty of "ensuring the comprehensiveness of such a list").

77 See id. at 51-52.

${ }^{78} 29$ C.F.R. § 1630.2(i) (1995).

${ }^{79}$ See HOUSE EDUC. AND LABOR REPORT, supra note 7, at 52. Thus, very minor impairments, such as an infected finger or a bad mood, do not constitute a disability for purposes of the ADA, as these trivial conditions do not substantially limit a major life activity. Cf. R. Bales, Once Is Enough: Evaluating When a Person Is Substantially Limited in Her Ability to Work, 11 HOFSTRA LAB. L.J. 203, 221-45 (1993) (offering suggestions and tests for determining when a person's disability substantially limits a major life activity). 
illness. ${ }^{80}$ Again, in order to be covered by the ADA, the person with a record of impairment must be substantially limited in a major life activity.

\section{c. Being "Regarded As" Disabled}

The third definition, "being regarded as having an impairment," abandons the "substantially limited" requirement in protecting those perceived to have a disability. ${ }^{81}$ For example, an employee believed by his employer to suffer from schizophrenia would be covered by the Act. ${ }^{82}$ This provision is especially notable as it protects even the individual who has no substantially limiting impairment at all; it is enough to be "regarded as" disabled. In interpreting an identical prong under section 504 of the Rehabilitation Act, the Supreme Court noted that the legislative history of the ADA evinces "Congress['s] acknowledge[ment] that society's accumulated myths and fears about disability and disease are as handicapping as are the physical limitations that flow from actual impairment. ${ }^{83}$ It is this third prong that attacks the consequences of stigma; an employer may not refuse to hire someone based on (fear of) negative reactions to the individual. $^{84}$

${ }^{80}$ See EEOC, TeChNiCAL Assistance MANUAL, supra note 25, at II-2(b).

${ }^{81}$ See id. at II-2(c).

${ }^{82}$ It is significant that this third prong is most frequently invoked in the context of Acquired Immune Deficiency Syndrome. See, e.g., Local 1812, Am. Fed'n of Gov't Employees v. Department of State, 662 F. Supp. 50, 54 (D.D.C. 1987) (holding that one is considered to have a handicap under the Rehabilitation Act if he or she is perceived as a carrier of the HIV virus).

${ }^{83}$ School Bd. v. Arline, 480 U.S. 273, 284 (1987). In articulating the rationale for this third prong, the Court noted that the effect of an impairment reaches others as well as the individual and need not be actual to be detrimental: being regarded as having an impairment "might not diminish a person's physical or mental capabilities, but could nevertheless substantially limit that person's ability to work as a result of the negative reactions of others to the impairment." Id. at 283 .

${ }^{84}$ See HOUSE EDUC. AND LABOR REPORT, supra note 7, at 53 ("[I]f an employer refuses to hire someone because of a fear of the 'negative reactions' of others to the individual ... that person is covered under the third prong of the definition of disability."). The goal of this prong is to ensure that mentally ill individuals are judged on their ability rather than on their disability. "One of the most important steps employers can take to ensure compliance with Title $I$ is a change in attitude stemming from the recognition that people with mental illnesses are individuals who should be judged on their ability." ZUCKERMAN ET AL., supra note 9, at 15 . 


\section{Mental Illness As a "Disability"}

Mental illness is second only to disability claims based upon back injuries as the leading source of $A D A$ discrimination charges. ${ }^{85}$ As noted earlier, there is no list of covered mental illnesses, and given the different degrees and types of mental illness, each claim must be decided on an individual basis. ${ }^{86}$ Mental illnesses that have been determined to come within the statutory definition of the Rehabilitation $\mathrm{Act}^{87}$ include: schizophrenia, ${ }^{88}$ paranoid schizophrenia, ${ }^{89}$ childhood schizophrenia, ${ }^{90}$ major depression (unipolar depression, suicidal depression, or depressive neurosis), ${ }^{91}$ manic-depressive syndrome (bipolar depression), ${ }^{92}$ borderline personality disorder, ${ }^{93}$ chronic mental illness, ${ }^{94}$ and

${ }^{85}$ In the first year after enactment of the ADA (as of July 1993), the EEOC received 12,670 ADA claims. Back injuries and mental illness were the two leading grounds, accounting for $18.5 \%$ and $9.8 \%$ of all claims, respectively. See Patrick L. Vaccaro \& Margaret R. Bryant, Looking Back on the First Year of the Americans with Disabilities Act, LEGAL MGMT., Jan.-Feb. 1994, at 12, 12.

${ }^{86}$ Cf. E.E. Black, Ltd. v. Marshall, 497 F. Supp. 1088, 1098 (D. Haw. 1980) ("Words are not precise symbols and statutory definitions are often unable to precisely define and cover all possible situations.").

${ }^{87}$ As the predecessor statute to the ADA, the Rehabilitation Act provides instruction in determining which mental illnesses will be recognized as impairments sufficient to warrant statutory protection. See Casey, supra note 16, at $397\left({ }^{\text {"C Congress }}\right.$ intended that the case law developed under the Rehabilitation Act be used to decide ADA questions."); supra note 64 (noting that the ADA was modeled in large part upon the Rehabilitation Act); supra note 74 (identifying the similarities between statutory language used in the ADA and the Rehabilitation Act). But see Barbara A. Lee, Reasonable Accommodation Under the Americans with Disabilities Act: The Limitations of Rehabilitation Act Precedent, 14 BERKELEY J. EMPLOYMENT \& LAB. L. 201, 235 (1993) (noting that the differences between the statutes cast doubt on the Rehabilitation Act's ability to predict judicial outcomes under the ADA).

${ }^{8 s}$ See Doe v. Colautti, 592 F.2d 704, 708 (3d Cir. 1979) (stating that Doe, a schizophrenic, was "handicapped" for purposes of the Rehabilitation Act); Bolthouse v. Continental Wingate Co., 656 F. Supp. 620, 625-26 (W.D. Mich. 1987) (stating that "there can be no doubt" that schizophrenia fits under the Rehabilitation Act's definition of handicapped).

${ }^{89}$ See Franklin v. United States Postal Serv., 687 F. Supp. 1214, 1218 (S.D. Ohio 1988) (placing paranoid schizophrenia in the handicapped category); see also infra notes $152-55$ and accompanying text (examining Franklin in the context of the direct threat qualification).

${ }^{90}$ See Gladys J. v. Pearland Indep. Sch. Dist., 520 F. Supp. 869, 876 (S.D. Tex. 1981) (describing childhood schizophrenia as a severe handicap).

${ }^{91}$ See Doe v. Region 13 Mental Health-Mental Retardation Comm'n, 704 F.2d 1402, 1408 (5th Cir. 1983) (accepting various forms of serious depression as handicaps).

${ }^{92}$ See generally Gardner v. Morris, 752 F.2d 1271 (8th Cir. 1985) (assuming throughout that manic depression is a handicap).

${ }_{93}$ See Doe v. New York Univ., 666 F.2d 761, 775 (2d Cir. 1981) (defining a severe 
severe psychiatric difficulties. ${ }^{95}$

In other circumstances, courts have refused to extend disability status to certain mental illnesses. ${ }^{96}$ In addition, the ADA expressly excludes certain mental illnesses, most conspicuously sexual disorders, from coverage, which has led to the criticism that the ADA "carve[s] out a space of permissive employer discrimination." 97 Specifically, the Act does not recognize its "List of 11 " disorders, which is comprised of transvestism, pedophilia, exhibitionism, voyeurism, transsexualism, gender identity disorders not resulting from physical impairment, other sexual behavior disorders, ${ }^{98}$ compulsive gambling, kleptomania, pyromania, and psychoactive substance abuse disorders resulting from current, illegal use of drugs. ${ }^{99}$

incapacity to handle stressful situations as a handicap).

${ }_{94}$ See Edge v. Pierce, 540 F. Supp. 1300, 1305 (D.N.J. 1982) (assuming the existence of a handicap in this situation).

${ }_{95}$ See Doe v. Marshall, 459 F. Supp. 1190, 1191 (S.D. Tex. 1978) (finding that the defendant was correctly labeled handicapped), vacated on other grounds, 622 F.2d 118 (5th Cir. 1980), cert. denied, 451 U.S. 993 (1981).

${ }^{96}$ See, e.g., Forrisi v. Bowen, 794 F.2d 931, 934 (4th Cir. 1986) (acknowledging that the plaintiff suffered from acrophobia but concluding that the impairment did not substantially limit a major life function); Ross v. Beaumont Hosp., 687 F. Supp. 1115, 1118-20 (E.D. Mich. 1988) (recognizing narcolepsy as a handicap but holding that abusive behavior, and not mental illness, was the basis for recommending final termination of employment); Matzo v. Postmaster Gen., 685 F. Supp. 260, 263 (D.D.C. 1987) (holding that a manic-depressive individual was not otherwise qualified for the position), aff d, 861 F.2d 1290 (D.C. Cir. 1988); Swann v. Walters, 620 F. Supp. $741,746-47$ (D.D.C. 1984) (disallowing paranoid schizophrenia as the basis of the plaintiff's claim as the claimant's termination was not based solely on the mental illness).

${ }^{97}$ Hiegel, supra note 39, at 1492.

${ }^{93}$ See id. at 1473-74.

${ }^{99}$ See 42 U.S.C. § 12211 (Supp. V 1993); see also Hiegel, supra note 39, at $1452 \mathrm{n} .9$ (demonstrating that the excluded disorders are defined in the DSM-III [revised by the DSM-IV] used by the drafters and arguing that these exclusions illustrate Congress's attempt to use the ADA to codify moral norms). The Act does cover alcoholics and recovered illegal drug abusers. See 42 U.S.C. \$ 12114(b)-(c); see also Lee, supra note 87, at 243-49 (noting the ADA's disparate treatment of alcohol and illegal drug abusers). For an in depth discussion of the ADA's coverage of addiction, see generally Henderson, supra note 9. By contrast, the Rehabilitation Act, protected current substance abuse users as long as their use did not present a threat to their work, property, or others. See Haggard, supra note 9, at 354-55. To demonstrate the complexity of the situation, note that statistics evidence a strong correlation between mental illness and substance abuse. See ZUCKERMAN ET AL., supra note 9, at 14-15. Over half of all adults who have suffered from substance abuse disorders have also had at least one mental illness; and $30 \%$ of adults with mental illness also have had substance abuse disorders. See id.

A piece of legislative history is of interest here. During congressional discussion 


\section{3. "Otherwise Qualified Individual" and "Essential Functions"}

In addition to having a disability, the individual must be qualified for the position in order to come within the ADA's protection. ${ }^{100}$ Two inquiries determine whether the individual is qualified for the job. ${ }^{101}$ First, the individual must be "otherwise qualified" for the position, meaning that she must meet the necessary, business-related job prerequisites. ${ }^{102}$ Second, the person must be able to perform the "essential functions" of the position with or without the employer's "reasonable accommodation." 103 Congress deemed the "essential functions" element important "to ensure that individuals with disabilities ... are not denied employment opportunities because they are unable to perform marginal functions of the position."104 "Essential," as distinguished from "marginal," functions are those duties that are fundamental to the position because either they are the reason the position exists, they are critical to the operation of the business, or they require specialized knowledge. ${ }^{105}$ An individual's diagnosable mental illness may render him unqualified. In Southeastern Community College v. Davis, ${ }^{106}$ the Supreme Court held that an individual

of which conditions ought to be excluded, Senator Armstrong proposed an amendment, which he justified on the basis of religious and moral convictions, that mandated that psychiatric disorders defined by the DSM-III-R [revised by the DSMIV] should be excluded from ADA coverage. See 135 CoNG. REC. S10,753-54 (daily ed. Sept. 7, 1989); 135 CONG. Rec. S10,772-74 (daily ed. Sept. 8, 1989). The Senator's retreat from this disturbing request came only after a reminder from Senator Domenici that both President Lincoln and Winston Churchill suffered from bipolar, or manic, depression. See 135 CoNG. REC. S10,778-79 (daily ed. Sept. 7 1989).

${ }^{100}$ The statute reads, in pertinent part: "The term 'qualified individual with a disability' means an individual with a disability who, with or without reasonable accommodation, can perform the essential functions of the employment position that such individual holds or desires." 42 U.S.C. $\$ 12111(8)$. The term "qualified" refers to current ability, not potential for future incapacitation. See HoUSE EDUC. AND LABOR REPORT, supra note 7, at 55.

${ }^{101}$ See EEOC, TEGhNical Assistance MANUAL, supra note 25, at II-3(1).

102 See id.

${ }^{103}$ See 42 U.S.C. § $12111(8)$.

104 EEOC, TECHNICAL ASSISTANCE MANUAL, supra note 25, at III.

${ }^{105}$ See id. app. B (providing interpretive guidance for 29 C.F.R. $\$ 1630.2(\mathrm{n})$ (1992)). An example of this essential-marginal distinction is helpful. For a secretary, typing would be an essential function; delivering copies to the offices 30 floors up, however, might be a marginal function such that an individual with severe acrophobia (fear of heights) could remain qualified for this position if the employer accommodates the request to delegate that task to another employee.

106442 U.S. 397 (1979). 
is not qualified for a position if his handicap precludes him from performing the essential functions of the job. ${ }^{107}$ In addition, absenteeism frequently disqualifies persons with mental illness as regular predictable attendance is an essential requirement of nearly all poșitions. ${ }^{108}$

\section{4. "Reasonable Accommodation"}

If a disabled employee has a viable $\mathrm{ADA}$ claim based upon satisfaction of the foregoing requirements, the employer, once made aware of the disability, may have a duty to provide reasonable accommodation. ${ }^{109}$ While this duty may be difficult for employers

${ }^{107}$ See id. at 406; see also Fields v. Lyng, 705 F. Supp. 1134, 1136 (D. Md. 1988) (holding that an individual diagnosed with borderline personality disorder with obsessive-compulsive features and side effects of anxiety and kleptomania, who was terminated for shoplifting, was not "otherwise qualified" to perform the essential functions of his job since "handicap discrimination laws protect only those who can do their job in spite of their handicap, not those who could do it but for their handicap"), aff'd, 888 F.2d 1385 (4th Cir. 1989).

${ }^{108}$ See, e.g., Walders v. Garrett, 765 F. Supp. 303, 310-12 (E.D. Va. 1991) (holding that a civilian employee who suffered from chronic fatigue immune dysfunction syndrome, resulting in frequent absenteeism, was not otherwise qualified to be a Navy librarian), affd, 956 F.2d 1163 (4th Cir. 1992); Matzo v. Postmaster Gen., 685 F. Supp. 260, 263 (D.D.C. 1987) (holding that a person suffering from bipolar (manic) depression was not otherwise qualified for a clerical position with the Post Office due to his very poor attendance record and frequent inability to work a full day), aff d, 861 F.2d 1290 (D.C. Cir. 1988).

${ }^{109}$ See EEOC, TEChnical Assistance MANUal, supra note 25, at III. Because employers need only accommodate "known limitations of a qualified individual with a disability," it is an employee's responsibility to make the employer aware of his mental illness. ZUCKERMAN ET AL., supra note 9, at 22. This is especially important for the mentally ill as their disabilities are often hidden. See supra note 37 and accompanying text. Thus, it is the employee's responsibility to make the employer aware of the disability and to request an accommodation. See ZUCKERMAN ET AL., supra note 9, at 22. Although it is the employer's duty to craft a reasonable accommodation, the employee may make suggestions. See id. Because of the individualized nature of mental illness, the employee is often the best person to suggest appropriate reasonable accommodations. See id. at 37. An employer must provide a reasonable accommodation but has no duty to accept one suggestion over another. See id. at 22. To ensure successful implementation of effective, workable solutions toward the best workplace environment, this process of negotiation requires open, confidential, and honest communication between the employer and employee. See id. at 4 (" $[\mathrm{T}]$ wo way communication and cooperation between employee and employer builds the trust that is necessary to overcome barriers to successful implementation of Title I and to achieve full integration of people with mental illness into the workplace."); see also Paul F. Mickey, Jr. \& Maryelena Pardo, Dealing with Mental Disabilities Under the ADA, 9 LAB. LAW. 531, 540 (1993) (advocating an open dialogue and input from both employer and employee in determining a reasonable accommodation). 
to meet, mental health and legal scholars have offered many suggestions. ${ }^{110}$ Accommodations appropriate for persons with mental illness include, but are not limited to, creating flexible or modified work schedules, putting communications in writing, counseling and educating employees and managers about mental illnesses, establishing conflict resolution mechanisms, making changes in the physical environment to minimize anxiety, maintaining good lighting, avoiding distractions and needless stimuli, restructuring job duties, presenting a congenial atmosphere, and providing positive feedback. ${ }^{111}$

\section{Employer Defenses to an ADA Claim}

An employer may escape ADA liability by rebutting the prima facie claim or by asserting an affirmative defense. Thus, as a threshold matter, the employer may challenge the requisite showing of disability; the ADA imposes no restrictions on the employer when the employee fails to establish disability. In addition, the ADA provides employers with two affirmative defenses, which, if successful, relieve the employer of the duty to accommodate reasonably a disabled employee. First, the employer need not grant a reasonable accommodation if doing so would impose an undue hardship. ${ }^{112}$ Since the cost of reasonably accommodating mentally

${ }^{110}$ For discussion of the reasonable accommodation requirement, see generally ZUCKERMAN ET AL., supra note 9, at 34-49; James A. Burstein, What Is "Reasonable Accommodation" Under the Americans with Disabilities Act?, PRAC. LAW., July 1992, at 63; Paul Carling, Reasonable Accommodations in the Workplace for Persons with Psychiatric Disabilities, in IMPLICATIONS OF THE AMERICANS WITH DISABILITIES ACT FOR PSYCHOLOGY, supra note 13, at 103, 103-36; Employers Encounter Difficulties, supra note 11, at 58; Russell H. Gardner \& Carolyn J. Campanella, The Undue Hardship Defense to the Reasonable Accommodation Requirement of the Americans with Disabilities Act of 1990, 7 LAB. LAw. 37, 38 (1991); Deborah Zuckerman, Reasonable Accommodations for People with Mental Illness Under the ADA, 17 MENTAL \& PHYSICAL DISABILITY L. REP. 311 (1993); Jeffrey O. Cooper, Comment, Overcoming Barriers to Employment: The Meaning of Reasonable Accommodation and Undue Hardship in the Americans with Disabilities Act, 139 U. PA. L. REV. 1423 (1991); Renée L. Cyr, Note, The Americans with Disabilities Act: Implications for Job Reassignment and the Treatment of Hypersusceptible Employees, 57 BROOK. L. REV. 1237 (1992); Haggard, supra note 9.

Perhaps the voluminous accumulation of literature discussing the meaning of "reasonable accommodation" is explained by the fact that this term of art is unique to the ADA. The Rehabilitation Act itself was silent as to this requirement; rather, "reasonable accommodation" was born of Department of Health and Human Services regulations. See Parmet, supra note 64 , at $341 \&$ n.31. Thus, the ADA's codification of "reasonable accommodation" marks a significant advancement in disability law.

${ }^{111}$ See ZUCKERMAN ET AL., supra note 9, at 44-45.

112 See 42 U.S.C. $\$ 12111(10)$ (Supp. V 1993). In determining whether or not 
ill employees is usually low, ${ }^{113}$ accommodations for the mentally ill rarely impose undue hardship, making employers more likely to rely on the second affirmative defense, the direct threat qualification (the "safety defense"). ${ }^{114}$ The following Part considers the current approaches and present dangers inherent in the application of the direct threat defense to ADA claims by the mentally ill.

\section{The SAFety DefEnSE}

\section{A. The Safety Defense: Defining the Direct Threat Standard}

An employer invokes the safety defense when she believes that hiring or keeping the employee would present a threat to safety in the workplace. Under the safety defense, a "direct threat" is defined as:

[A] significant risk of substantial harm to the health or safety of the individual or others that cannot be eliminated or reduced by reasonable accommodation. The determination that an individual poses a 'direct threat' shall be based on an individualized assessment of the individual's present ability to safely perform the essential functions of the job. This assessment shall be based on a reasonable medical judgment that relies on the most current medical knowledge and/or on the best available objective evidence. In determining whether an individual would pose a direct threat, the factors to be considered include:

employing the individual would force the employer to sustain an undue burden, the ADA proposes several factors for consideration: the financial resources of the employer, the impact of the accommodation on the workplace, the size, location, and type of business involved, and the number of persons employed at the workplace. See id.; see also Gardner v. Morris, 752 F.2d 1271, 1283-84 (8th Cir. 1985) (finding that providing a manic-depressive individual, who successfully controlled his mental illness with lithium, with a physician and on-site laboratory facilities was an undue hardship because it was cost prohibitive). But cf. Cooper, supra note 110, at 1453-54 (criticizing the holding in Gardner and arguing that this type of accommodation is reasonable under the ADA).

${ }^{113}$ See Zuckerman, supra note 110, at 314 (stating that more than two-thirds of all accommodations cost less than $\$ 500$ ). Although undue hardship is typically couched in financial terms, the defense is not limited to excessive economic demands. An accommodation will also impose undue hardship when it is "extensive," "substantial," "disruptive," or when it "fundamentally alter[s] the nature or operation of the business." ZUCKERMAN ET AL., supra note 9, at 23.

11 Curiously, the direct threat standard was not originally codified as an employer defense. Only in response to concerns that the direct threat standard implied a presumption of risk, which the employee had to rebut as a part of the prima facie claim, did the EEOC place the direct threat qualification within the ADA. See Equal Employment Opportunity for Individuals with Disabilities, 29 C.F.R. § 1630.2(r) (1992). 
1) The duration of the risk;

2) The nature and severity of the potential harm;

3) The likelihood that the potential harm will occur; and

4) The imminence of the potential harm. ${ }^{15}$

The ADA exempts the employer from her duty to reasonably accommodate an otherwise qualified disabled individual when the presence of that individual as an employee in the workplace creates a direct threat. ${ }^{116}$ Congress defines "direct threat" as "a significant risk to the health or safety of others that cannot be eliminated by reasonable accommodation. ${ }^{117}$ The direct threat must relate to the current ability of the individual to perform safely the job's essential functions. ${ }^{118}$ Moreover, in order to invoke the defense, the employer must clearly identify the specific risk posed by the employee. ${ }^{119}$ Even if a direct threat exists, the employer may not use the defense if a reasonable accommodation would enable the employee to work safely; rather, the employer must make an affirmative effort to eliminate or reduce the direct threat. ${ }^{120}$

\section{B. The EEOC Interpretive Standard: Risk-to-Self-or-Others}

Through its regulations, the EEOC purports to give guidance to employers in assessing the direct threat and invoking the safety defense. The EEOC has already recognized the safety defense's potential for premature application to mentally ill individuals. In its guidelines for implementation of the employment provisions of the ADA, the EEOC stated that, "[f]or individuals with mental or emotional disabilities, the employer must identify the specific behavior on the part of the individual that would pose the direct threat." ${ }^{121}$ Thus, in helping Congress to shape the

11529 C.F.R. $\S 1630.2(r)$ (1995). As will be discussed, this definition is a codification of the Supreme Court's decision in School Bd. v. Arline, 480 U.S. 273 (1981). The force of this Comment is that a fifth factor, concerning psychotropic medication, should be added to this definition. See infra part IV.

${ }^{116}$ See 42 U.S.C. § 12113(b) (Supp. V 1993).

${ }^{117} 42$ U.S.C. $\$ 12111(3)$.

${ }^{118}$ See 42 U.S.C. § $12111(8)$.

${ }^{119}$ See Mary Anne Sedey, The Threat to the Safety Defense Under the Americans with Disabilities Act: Its Source, Surrounding Caselaw, and Interpretation, 39 FED. B. NEwS \& J. 96, 98 (1992) (noting that, in interpreting the safety defense, the EEOC responded to the concerns of disability-rights groups by "narrowly confin[ing]" the defense).

120 See EEOC, TEChNICAL ASSISTANCE MANUAL, supra note 25, at IV-5.

12156 Fed. Reg. 35,745 (1991). The commentary contains a similar requirement for physical disability. See id. 
ADA, the EEOC regulations embodied some skepticism regarding the use of this defense and used this foresight to attempt to confine the defense by construing it narrowly. ${ }^{122}$ Later EEOC regulations, however, interpret the statute to adopt a "risk-to-self-orothers" standard. ${ }^{123}$ The adoption of this standard generated critical comments from disabilities rights groups, ${ }^{124}$ who eventually persuaded the EEOC to make modest changes to this interpretation. ${ }^{125}$ Nevertheless, a broad scope of unacceptable risk persists, and it is with this standard that disabled employees must contend.

The EEOC interpretation has been criticized on at least four grounds. ${ }^{126}$ Specifically, opponents of the interpretation argue that it is paternalistic, ${ }^{127}$ inconsistent with legislative history

${ }^{122}$ See 29 C.F.R. § 1630.2(r) (1995); see also Bonnie P. Tucker, The Americans with Disabilities Act Interpreting the Title I Regulations: The Hard Cases, 2 CORNELL J.L. \& PUB. POL'Y 1, 11-12 (1992) (emphasizing that the direct threat analysis must be individualized and that "a statistically significant risk of harm" is insufficient to establish the safety defense).

${ }^{123}$ Compare 42 U.S.C. $\$ 12113$ (b) (setting out the ADA qualification standard that "an individual shall not pose a direct threat to the health or safety of other individuals in the workplace") with 29 C.F.R. $\$ 1630.15(\mathrm{~b})(2)$ (1995) (EEOC guidelines) (adopting a risk-to-self-or-others standard for the purposes of Title I by interpreting the ADA to mean a direct threat "to the health or safety of the individual or others" (emphasis added)).

${ }^{124}$ See 29 C.F.R. $\$ 1630.2(\mathrm{r})$ (1992) ("Many disability rights groups and individuals with disabilities . . . expressed concern that the reference to 'risk to self' would result in direct threat determinations that are based on negative stereotypes and paternalistic views about what is best for individuals with disabilities.").

${ }^{125}$ Specifically, the EEOC responded with five changes to its proposed rule. First, the EEOC sharpened its definition of direct threat to highlight that a risk need not be completely eliminated, but rather just reduced to a safe level by reasonable accommodation. Second, the EEOC expanded the scope of relevant evidence that should be taken into account in applying the standard and emphasized the need for individualized assessments. Third, the EEOC precluded predictions of future risk as an element of the direct threat evaluation. Fourth, an imminence requirement was added to the direct threat standard. Finally, the EEOC emphasized that the safety defense may be invoked against any employee, not just disabled ones. See Neal, supra note 71 , at $487 \mathrm{n} .24$ (outlining the EEOC changes and criticizing the fifth change as "mere rhetoric").

${ }^{126}$ See id. at 495-513 (advancing the arguments discussed below, and advocating either that the EEOC abandon the risk-to-self standard or, in the alternative, that the courts refuse to enforce this interpretation); Parry, supra note 1 , at 531 (criticizing the EEOC approach because it contradicts notions of self-determination and leaves open the possibility that a "so-called threat" could be used to disguise antidisability animus).

127. See infra note 132 and accompanying text (explaining the paternalism argument). 
and congressional intent, ${ }^{128}$ contrary to Rehabilitation Act case law, ${ }^{129}$ and an excessive and unauthorized exercise of power. ${ }^{130}$

${ }^{128}$ The EEOC justifies its interpretation as being supported by "the legislative history of the ADA and the case law interpreting $\$ 504$ of the Rehabilitation Act." 56 Fed. Reg. 35,730 (1991) (EEOC rule). The EEOC standard is inconsistent with the plain language of the Act, which clearly contemplates a risk-to-others standard. See supra note 123 (comparing the ADA language with the EEOC guidelines with respect to the direct threat qualification). It is telling that, in interpreting the same direct threat qualification standard for Title III of the ADA, the Department of Justice ("DOJ") used a risk-to-others standard. See 28 C.F.R. \$ 36.208(a) (1995) (DOJ rule) (implementing a risk-to-others standard with respect to the Title III public accommodations provisions of the ADA). The inconsistency between the DOJ and the EEOC interpretations hardly lends support to the EEOC position that the ADA manifests clear legislative support for its interpretation. See supra note 125 and accompanying text. Absent a distinction between the goals of Title I and Title III, this inconsistency remains problematic.

${ }^{129}$ To the extent that Rehabilitation Act case law informs implementation of the ADA, see supra notes $64,74,87$, it is troubling that the EEOC justifies its standard based upon the Rehabilitation Act. In fact, that statute provides little guidance, as the cases under the Rehabilitation Act itself perpetuate uncertainty by invoking different standards in different jurisdictions. Some courts, consistent with statutory language, have employed a "risk-to-others" standard. See, e.g., Chalk v. United States Dist. Court, 840 F.2d 701, 710 (9th Cir. 1988); Strathie v. Department of Transp., 716 F.2d 227, 232-33 (3d Cir. 1983). Others have invoked a "risk-to-self-or-others" formulation. See, e.g., Chiari v. League City, 920 F.2d 311, 316 (5th Cir. 1991); Mantolete v. Bolger, 767 F.2d 1416, 1421 (9th Cir. 1985). A few courts have adopted a "risk-to-self" standard. See, e.g., Bentivegna v. United States Dept. of Labor, 694 F.2d 619, 622 (9th Cir. 1982); Kampmeler v. Nyquist, 553 F.2d 296, 299-300 (2d Cir. 1977). In fact, the safety defense case law under the Rehabilitation Act "exhibit[ed] no pattern of distinction with regard to why a given standard [was] better or worse than another [as] ... [no] position [was] fully supported by the case law and [all] positions . . . cite[d] cases with an opposing viewpoint." Neal, supra note 71, at 502. Thus, relying on Rehabilitation Act precedent to justify the EEOC standard ultimately fails.

${ }^{130}$ The risk-to-self component of the EEOC's risk-to-self-or-others standard may violate the Cheuron doctrine, established by the Supreme Court in Chevron U.S.A. Inc. v. Natural Resources Defense Council, Inc., 467 U.S. 837 (1984). Chevron establishes that an agency's interpretation of an ambiguous statute must be accepted unless it is "arbitrary, capricious, or manifestly contrary to the statute." Cheuron, 467 U.S. at 844. Still, "the court, as well as the agency, must give effect to the unambiguously expressed intent of Congress." Id. at 842-43. Since the ADA clearly states that direct threat means significant risk of harm to others, the EEOC has arguably exceeded its statutory authority in contradicting, by grafting onto, the plain language of the statute. It remains uncertain whether the regulation will withstand the inevitable flood of litigation that will challenge it. While courts typically follow an agency's interpretation, they may refuse to follow an EEOC regulation "where there are 'compelling indications that it is wrong."' Espinoza v. Farah Mfg. Co., 414 U.S. 86, 94-95 (1973) (quoting Red Lion Broadcasting Co. v. FCC, 395 U.S. 367, 381 (1969)); see also General Elec. Co. v. Gilbert, 429 U.S. 125, 144-45 (1976) (refusing to follow EEOC regulations that contradicted Congress's "plain meaning"). 
Of these criticisms, the concern for paternalism deserves particular attention in the mental illness context. Since the autonomy of the mentally ill already suffers because of their needs to rely on medication and to work to maintain societal integration, ${ }^{131}$ the EEOG standard should reflect the capability, rather than the deviance, of persons with mental illness. Because paternalism is inherently condescending, ${ }^{132}$ it inescapably results in discrimination. "Paternalism is perhaps the most pervasive form of discrimination for people with disabilities and has been a major barrier to such individuals. ${ }^{n 133}$ Since pity is a common

${ }^{131}$ See supra note 3.

192 The values of individual autonomy and personal sovereignty, paralleling the antipaternalism movement, have been embraced since the 19th century. Philosopher John Stuart Mill proclaimed the classic argument against paternalism:

[T] he only purpose for which power can be rightfully exercised over any member of a civilized community, against his will, is to prevent harm to others. His own good, either physical or moral, is not a sufficient warrant. ... Over himself, over his own body and mind, the individual is sovereign.

John StuART Mill, ON LiberTy 68-69 (Gertrude Himmelfarb ed., Penguin Books 1985) (1859). Mill's antipaternalistic philosophy has not gone unchallenged. See Neal, supra note 71, at 509 (concluding that "modern society has not adopted Mill's anti-paternalistic message"). Among the most significant obstacles to Mill's message is the doctrine of parens patriae. Parens patriae, literally "parent of the country," refers to "the principle that the state must care for those who cannot take care of themselves," such as minors or the mentally ill. BLACK's LAW DICTIONARY 1114 (6th ed. 1990). The doctrine presumes that the mentally ill are, by their very nature, unable to make decisions that are in their best interest; it equates mental illness with irrationality. Historically, courts have invoked the parens patriae rationale for confining the mentally ill in an effort to protect society from deviant behavior. See, e.g., O'Connor v. Donaldson, 422 U.S. 563, 580-84 (1975) (Burger, C.J., concurring) (finding a liberty/due process violation for involuntary and unnecessary commitment of an individual). Significantly, the Supreme Court has described the parens patriae power as the right of "the sovereign or his representative as the 'general guardian of all infants, idiots, and lunatics." Hawaii v. Standard Oil Co., 405 U.S. 251, 257 (1972) (quoting 3 William Blackstone, Commentaries *47).

Thus, States, by and through their general police powers preserved by the Constitution, see U.S. CoNST. amend. X, have enjoyed significant control in evaluating and managing risk for the mentally ill. This Comment is principally concerned that the ADA's safety defense may give an analogous, although less powerful, quasi-parens patriae power to employers. While such a result may not rise to the level of excluding the legally incompetent mentally ill from society, it may impermissibly exclude them from employment. Clearly, the State may do the former; the EEOC, however, must act responsibly to ensure that an employer may not do the latter. While parens patriae is justifiable to involuntarily commit the incompetent mentally ill to an institution, it is unacceptable as a rationale to involuntarily exclude the competent mentally ill from employment.

${ }^{133}$ HOUSE EDUC. AND LABOR REPORT, supra note 7, at 74. 
response to the mentally $i l 1,{ }^{134}$ the paternalism that naturally follows renders these individuals more susceptible and vulnerable to discrimination under the risk-to-self standard. ${ }^{135}$ Indeed, Congress addressed this very concern during the evolution of the ADA. ${ }^{136}$

\section{Current Guidelines for Safety Defense Interpretation:}

\section{The Arline Factors and Reasonable Medical Judgment}

The EEOC's broad interpretation of employer risk, manifested in the risk-to-self-or-others standard, necessitates judicial monitoring because it symbolizes a retreat from Congress's manifest intent to empower, rather than to patronize, the disabled.

\section{The Arline Factors}

The EEOC offers four factors, adopted from the Supreme Court's decision in School Board of Nassau County v. Arline, ${ }^{137}$ for an employer to consider when assessing a potential direct threat:

(1) The duration of the risk;

(2) The nature and severity of the potential harm;

(3) The likelihood that the potential harm will occur; and

(4) The imminence of the potential harm. ${ }^{138}$

${ }^{134}$ See Blanck, supra note 28, at 793 (discussing the Harris Poll findings which revealed that "public views of 'embarrassment and pity' are common towards persons with disabilities").

${ }^{135}$ See Neal, supra note 71, at 508-09 (discussing the paternalistic nature of the EEOC's risk-to-self standard). It is troubling to contemplate that the existence of mental impairments in the workplace could be the catalyst for the EEOC's broad interpretation of risk. The standard of risk adopted by other civil rights legislation, such as Title VII of the Civil Rights Act of 1964, 42 U.S.C. $\$ \$ 2000 \mathrm{e}$ to $2000 \mathrm{e}-17$ (1988 \& Supp. V 1993), and the Age Discrimination in Employment Act of 1967 ("ADEA"), 29 U.S.C. $\$ \$ 621-634$ (1988 \& Supp. V 1993), is a risk-to-others test. Of these three antidiscrimination statutes (Title VII, ADEA, and ADA), it is significant that only the ADA pratects against mental impairments and only the ADA invokes a risk-to-self standard.

${ }^{136}$ See HOUSE EDUC. AND LABOR REPORT, supra note 7, at 72 (stating that "[i]t is critical that paternalistic concerns for the disabled person's own safety not be used to disqualify an otherwise qualified applicant").

${ }^{137} 480$ U.S. 273, $284-86$ (1987) (holding that there was insufficient evidence to determine if a school teacher with tuberculosis presented a direct threat of safety, and thus was not otherwise qualified, under $\$ 504$ of the Rehabilitation Act).

198 29 C.F.R. § 1630.2(r) (1995); see also supra note 114. 
Arline itself involved a contagious physical disease and not a mental illness. ${ }^{139}$ Thus, although the case may be applauded for laying out a four-prong test for direct threat standard interpretation, its applicability to mental illness is uncertain, and its terms remain ambiguous.

\section{The Reasonable Medical Judgment Standard}

The legitimacy of an employer's safety defense revolves around her prediction of the employee's dangerousness. ${ }^{140}$ The EEOC dictates that the employer must base her direct threat assessment on "a reasonable medical judgment that relies on the most current medical knowledge and/or on the best available objective evidence. ${ }^{141}$ This provision clearly contemplates mental health experts assessing the dangerousness of a mentally ill individual. ${ }^{142}$ While in theory this guidance is helpful, in practice it may not suffice to ensure that this evaluation does not incorporate myths, irrational fears, paternalistic stereotypes, or any subjective beliefs about the individual or the disability. ${ }^{143}$ Reliance on medical knowledge is especially difficult in the area of mental illness because of the irregular and episodic nature of this impairment. Moreover,

${ }^{199}$ See 480 U.S. at 276 . Arline, a school teacher, suffered from tuberculosis; the alleged threat she presented to her students was her contagiousness. See id. at 281. After setting out the test for determining direct threat, the Supreme Court held that the Rehabilitation Act protected Arline since impairments that "might not diminish a person's physical or mental capabilities ... could nevertheless substantially limit that person's ability to work as a result of the negative reactions of others to the impairment." Id. at 283. Congress significantly cut back the protection of Arline by stating that a person suffering from a contagious disease will not be considered handicapped if the disease causes a "direct threat to the health and safety" of others. 29 U.S.C. $\S 706(8)$ (D) (Supp. V 1993).

${ }_{140}$ Unlike criminal law, which is based on past actions, mental health law evaluates both past and future actions, especially future. See CURT R. BARTOL, PsYCHOLOGY AND AMERICAN LAW 100 (1983). It is inescapable that employers will call upon this subjective element of mental health law in advancing the affirmative safety defense against the claims of mentally ill individuals.

14129 C.F.R. § 1630.2(r) (1995); see also EEOC, TECHNICAL AsSISTANCE MANUAL, supra note 25, at IV-5 (requiring strict guidelines for a finding of direct threat such that it "cannot be based on mere speculation unrelated to the individual in question"). law).

${ }^{142}$ See supra note 39 (discussing the role of mental health specialists in disability

${ }^{143}$ See BARTOL, supra note 140, at 107 (noting that even psychiatrists and psychologists are poor at assessing the behavior of the mentally ill and predicting dangerousness, and that often these experts themselves "rely on hunches, speculation, vague clinical judgment, and theoretical prejudice"). 
the definitions and diagnoses of mental illness remain in constant flux. ${ }^{144}$ If the reasonable judgment standard evolves into a battle of the experts, a mire of clinical predictions providing little guidance to employers will result.

If these basic mental health issues are so bedeviling to a practicing psychiatrist, imagine the variation and complexity of issues facing employers who will have to address the needs of mentally-disabled employees, who may run the gamut from a salesman with psychotic delusions, to an assembly line worker with attention deficit disorder, to a bus driver with panic attack disorder. ${ }^{145}$

\section{The Need for Stricter Guidelines and Additional Considerations}

The safety defense is "an especially sticky area" for employers since it requires that the employer "balance concerns about violence with the mandates of the ADA."146 The problem with the current standards is that they do not adequately shield the mentally ill from the risk that employers will overuse the safety defense with respect to them. Empirical evidence illustrates that employers embrace the myths that disabled employees plague the workplace with safety risks $^{147}$ and that those with mental disabilities pose a special danger. ${ }^{148}$

Thus, preceded by their reputation as a dangerous group of individuals, the claims of the mentally ill are vulnerable to the direct

${ }^{144}$ Definitions of mental illness have changed even from the time of the ADA's enactment. In 1990, when the ADA was passed, Congress relied on the DSM-III-R. See AMERICAN Psychiatric Ass'N, Diagnostic and Statistical MaNUAl OF MENTAL DISORDERS (3d ed. 1987). By 1994, when the ADA was in full effect, the APA had issued a fourth edition of the manual, DSM-IV. See DSM-IV, supra note 9. Mental health professionals have noted the difficulties presented by the ambiguous definitions of mental illness. See, e.g., Yale Kramer, Schizophrenia and Psychiatry's Limits, WALL ST. J., Mar. 9, 1994, at A12 (stating that ambiguity results from the fact that the specific causes of mental illness remain unknown).

${ }^{145}$ Pechman, supra note 12 , at 22.

${ }^{146} I d$. at 26.

${ }^{147}$ See Blanck, supra note 28 , at 698 (reporting that research discredits the belief that disabled employees jeopardize the safety of the workplace).

${ }^{148}$ Cf. Peter Margulies, The Cognitive Politics of Professional Conflict: Law Reform, Mental Health Treatment Technology, and Citizen Self-Governance, 5 HARV. J.L. \& TECH., Spring 1992, at 25, 34 ("Criminal acts by people with mental disabilities are memorable while the mundane lives led by most people with mental disabilities melt into the mainstream."); Zuckerman, supra note 110, at 312 (noting that the myths and stereotypes surrounding mental illnesses lead employers to conclude that "a mental illness makes the person unable to interact with others"). 
threat defense. By interpreting this defense to have a "risk-to-self" component, the present EEOC standard justifies an employer's subjective concern that a mentally ill employee is more likely to engage in self-mutilation or other self-destructive behavior. ${ }^{149}$ The EEOC has provided a crutch, then, for employers who simply do not want disabled individuals in their midst.

There are, to be sure, situations in which the safety defense correctly applies. A clear history of repeated violence substantiated by previous instances manifesting dangerousness, for example, would warrant the invocation of the direct threat qualification. Thus, one court asked: "How many times must violence be overlooked before a 'reasonable accommodation' has been achieved?"150 The preceding Parts looked at the tests courts have used to respond to this question. Use of the tests above is not justified in cases involving the mentally ill, however, since they do not adequately account for the predominant treatment of the mentally ill. The present EEOC guidelines wholly ignore the use of medication to treat the mentally ill as an element of the direct threat qualification. To achieve the goals of the ADA, the law must recognize and accommodate the use of psychotropic medication. Given the widespread and successful use of psychotropic medication as a method of controlling the symptoms of mental illness, the absence of this consideration renders the guidelines incomplete.

${ }^{149}$ See John W. Parry, Mental Disabilities Under the ADA: A Difficult Path to Follow, 17 MENTAL \& PhySICAL DiSABILITY L. REP. 100, 102 (1993) (claiming that "Congress did not intend to include self-harm under the definition of direct threat"); see also Albert Rosen, Detection of Suicidal Patients: An Example of Some Limitations in the Prediction of Infrequent Events, $18 \mathrm{~J}$. CoNSULTING PSYCHOL. 397, 401 (1954) (finding that suicide is an infrequent and largely overpredicted event and that very few patients who are severely depressed or threaten suicide actually commit the act). But cf. ZUCKERMAN ET AL., supra note 9, at 64 (acknowledging that 15\% of persons with severe depression commit suicide compared to only $1 \%$ of the general population). Other reasons for invoking the defense are also unacceptable, such as increased insurance costs and fear of potentially costly compensation claims. Cf. Mary T. Giliberti, The Application of the ADA to Distinctions Based on Mental Disability in Employer-Provided Health and Long-Term Disability Insurance Plans, 18 MENTAL \& PHYSICAL DISABILITY L. REP. 600, 601-03 (1994) (discussing the impact of the ADA on insurance plans and arguing that the ADA unfairly permits insurers to put limits on mental health coverage). 1988).

${ }^{150}$ Franklin v. United States Postal Serv., 687 F. Supp. 1214, 1219 (S.D. Ohio 


\section{A Proposed STANDARD}

\section{A. Extending the Arline Factors to Include the Use of Medication in the Direct Threat Assessment}

If left unchecked, the safety defense threatens to swallow the ADA's goal of inclusion with respect to the mentally ill. Together with the EEOC, courts must refuse to allow employers to use the safety defense when it has the effect of ostracizing the mentally ill and the illegal consequence of unfairly denying them employment. Thus, this Comment proposes that a fifth factor be added to the Arline test of direct threat. ${ }^{151}$ This fifth factor should require specific consideration of the ameliorative effect of psychotropic medication on the safety risk in the direct threat analysis. Thus, only a concrete showing of a history of violence or abuse due to mental illness that cannot be controlled by psychotropic medicine, which is practically certain to arise in the workplace, justifies the safety defense.

By controlling any foreseeable threat to self or others in the workplace, the use of medication satisfies the concerns underlying the safety defense. Thus in applying the direct threat standard to ADA claims by mentally ill employees, courts should look to a fivefactor test:

1) The duration of the risk;

2) The nature and severity of the potential harm;

3) The likelihood that the potential harm will occur;

4) The imminence of the potential harm; and

5) The ameliorative effect of psychotropic medication.

The concerns raised by the use of psychotropic medication in the workplace render it necessary to look at how an individual's use of psychotropic medication will be implemented. The individualized inquiry with respect to psychotropic medication is threefold. First, to what extent can the employer compel a mentally ill employee to take prescribed psychotropic medication as a condition of employment? Second, to what extent does the employer have a duty to accommodate any side effects of medication? Third, and finally, who will bear the cost of required medication? The remainder of this analysis is devoted to answering these questions.

\footnotetext{
${ }^{151}$ See supra notes 114, 138 and accompanying text (outlining the current fourfactor test).
} 


\section{B. The Convergence of Medication and Direct Threat}

Direct threat and the use of psychotropic medication by a mentally ill employee came together under the Rehabilitation Act in Franklin $v$. United States Postal Service, ${ }^{152}$ a case which considered the termination of an employee who suffered from paranoid schizophrenia. Franklin's mental disability was characterized by a propensity for violence, which she controlled through antipsychotic medication. The court held that a person who has a mental illness that is controllable by medication but does not take such medication is not an "otherwise qualified handicapped person." 153 The court's conclusion, however, has been criticized because the evidence of potential threat, which included previous incidents of belligerence, was not work-related. ${ }^{154}$

The ADA does not address the proper role of medication in the workplace. Inevitably, the courts will face the question of whether an employer can require a mentally ill employee to take prescribed medication as a condition of employment-a question considered below. ${ }^{155}$

\section{The Role of Medication in the Direct Threat Analysis}

Mental illness is often treated with psychotropic medication, and this medication presents a compelling solution for treating and accommodating a mentally ill employee while reducing any possible threat both to the individual and to others in the workplace. For example, lithium might reduce the suicidal tendencies of a bus driver suffering from severe depression while simultaneously removing the related threat to the passengers. These medications, however, are a mixed blessing for the mentally ill since they often have severe side effects that may exacerbate stigma. ${ }^{156}$ The

152687 F. Supp. 1214 (S.D. Ohio 1988).

${ }^{153} \mathrm{Id}$. at 1218 .

${ }^{154}$ See Parry, supra note 149, at 106 (arguing that a more reasonable analysis would look at the potential for violence as it directly relates to the individual's behavior as an employee).

${ }^{155}$ Indeed, the courts have already considered this issue to a limited extent. See, e.g., Muller v. Automobile Club, 897 F. Supp. 1289, 1296 (S.D. Cal. 1995) (rejecting the plaintiff's claim that she had a cognizable disability due to medicinal side effects because she was no longer on the medication and there was no indication that the side effects continued); EEOCv. Union Carbide Chems. \& Plastics Co., No. CIV.A.94103, 1995 WL 495910, at *2 (E.D. La. Aug. 18, 1995) (holding that an employee suffering from bi-polar (manic depressive) disorder is a qualified individual under the ADA even though his condition may be controlled by medication).

${ }^{156}$ Persons suffering from schizophrenia, for instance, experience delusions and 
adverse and significant consequences of such side effects may lead mentally ill persons to forgo the medication altogether, thereby directly influencing their performance in the workplace. The employer has a legitimate interest, then, in the mentally ill employee's decision regarding the use of psychotropic medication. A balance between the needs and interests of the employer and the employee must be struck because an employee who must rely on medication to function in the workplace "experience[s] directly both the isolation of mental illness and the intrusiveness of medical interventions." 157

\section{Pros and Cons of Medication in the Workplace}

\section{Medication Encourages Integration}

Recent medical advances contributing to a better understanding of the interaction between mind and body have markedly increased the success rate of treating mental illness with psychotropic drugs. ${ }^{158}$ For the individual, successful treatment with medication is a release from the symptomatic prison and an integration into the workforce of America. For the employer, the successful use of medication signals the diminishment of the undesirable symptoms of mental disorder within the work environment and is an incentive encouraging such treatment. A mentally ill employee whose symptoms disappear with medication requires fewer "reasonable accommodations" and can contribute more to the productive working environment.

\section{Medication Imposes Side Effects}

The serious side effects accompanying many psychotropic drugs may outweigh the benefits of such treatment. ${ }^{159}$ The doubleedged implications for the employer of a disabled employee are

hallucinations. Drugs, such as haldol, thorazine, and prolixin, which have been used to treat schizophrenia, result in stigmatizing adverse effects. Among the most grave and widely cited negative side effects of psychotropic drugs is the onset of tardive dyskinesia, an irreversible disorder of the central nervous system that causes involuntary bodily twitching, as well as enlargement and rolling of the tongue. See Margulies, supra note 148, at 28-29; infra note 161 .

${ }^{157} I d$. at 49.

${ }^{158}$ See ZUCKERMAN ET AL., supra note 9, at 67.

${ }^{159}$ See id. (noting that a mentally ill person may prefer the comfort of known symptoms, for example, delusions, over the uncertainty of adverse side effects). 
readily apparent. The individual afflicted with schizophrenia who opts not to take antipsychotic medication to diminish her hallucinations will impose greater needs for accommodation than the individual relieved of that symptom. The use of psychotropic medication by an employee, however, forces the employer to accommodate and consider any side effects of the medication. Side effects emerge because medications do not cure the individual of the disorder, but rather control the symptoms by regulating the body's biological and chemical imbalances. ${ }^{160}$ While treatable themselves, through regulation and monitoring of medication levels, side effects may produce additional conditions that require employer accommodation. ${ }^{161}$ Among the most common side effects that will require reasonable accommodation are: nausea, headaches, nervousness, blurred vision, sleepiness, dizziness, low blood pressure, dry mouth, severe thirst, diminished memory, rapid heartbeat, restlessness, muscle stiffness and spasms, shaking, slowed movement and speech, and tardive dyskinesia. ${ }^{162}$

\section{E. Implications for Employers Under the Direct Threat Standard}

Having considered the pros and cons of including and accommodating medication in the safety defense standard, three conclusions, responding to the three questions posed earlier, will inform the employer's prospective treatment of mentally ill employees. First, the employer should be able to compel the use of psychotropic medication as a condition of employment where the employee would otherwise present a direct threat. ${ }^{163}$ As in Franklin $v$. United States Postal Service, ${ }^{164}$ where an employee presents a

${ }^{160}$ See id. at 11. For the layperson, an analogy may be drawn to aspirin, which reduces a fever without eradicating the underlying infection. See id.

${ }^{161}$ See id. at 68 (evaluating this impact of side effects).

${ }^{162}$ See id. at 68-69. Tardive dyskinesia presents a special concern since it affects $15 \%$ to $20 \%$ of individuals under the extended treatment of antipsychotic medication. See id. at 69; supra note 156.

${ }^{163}$ Of course this Comment does not argue simply that an employer can require an employee to take medication; even a state cannot impose such intrusion on an individual. See infra note 165 (discussing the ADA's impact on the controversy surrounding mandatory medication of the institutionalized mentally ill). Rather, this Comment seeks to offer/suggest a compromise where the mentally ill person who seeks employment faces challenges presented by the ADA's safety defense. Allowing employers to condition employment on proper medication, and then imposing on employers the burdens of accommodation and cost, the mentally ill are able to enter the workforce with a significantly lower direct threat obstacle.

${ }^{164} 687$ F. Supp. 1214 (S.D. Ohio 1988). 
practical certainty of threat in the absence of medication, such treatment may be required. ${ }^{165}$

Second, to the extent employers can require the use of medication as a condition of employment, employers will also be responsible for accommodating the consequent side effects.

Third, the employer should bear the cost under this direct threat guideline unless such cost represents an undue burden. High cost may deter the mentally ill individual from taking prescribed medication. As the employer inevitably possesses greater financial resources, a disabled employee can expect the employer to reimburse the employee for the cost of necessary psychotropic medication or, in the alternative, to provide health insurance which covers these medical costs. ${ }^{166}$ While neither the ADA, nor the

165 This inquiry into the mentally ill individual's use of psychotropic medication reveals the ADA's far-reaching implications and its potential to create an impact in areas never contemplated by Congress. The ADA goes beyond its "breathtaking" civil rights scope to "require [the] rethinking [of] legal doctrines that have dominated mental disability law and preoccupied the courts for two decades." Milstein et al., supra note 6, at 1247. Specifically, commentators have suggested that the ADA casts serious doubt on the state's ability to compel a psychiatric patient to take prescribed medication against his will. See id. The right of an institutionalized mentally ill patient to refuse medication has traditionally invoked a strict Fourteenth Amendment substantive due process analysis. Courts have oscillated on this issue, producing a somewhat confusing and erratic body of jurisprudence. See Dennis E. Cichon, The Right to "Just Say No": A History and Analysis of the Right to Refuse Antipsychotic Drugs, 53 LA. L. REV. 283, 326-30 (1992) (discussing cases in which an individual's right to be free from governmental intrusion has been grounded in substantive due process principles such as personal security and right to privacy); Brian Shagan, Note, Washington v. Harper: Forced Medication and Substantive Due Process, 25 CONN. L. REv. 265, $271-73$ (1992) (discussing cases in which courts have found substantive due process rights to refuse antipsychotic medication). The Eighth Circuit has gone as far as to allow a hospital to force an inpatient with a mental illness to take psychotherapeutic drugs against his will. See Dautremont v. Broadlawns Hosp., 827 F.2d 291, 300 (8th Cir. 1987) (upholding the decision to forcefully administer drugs because the state's legitimate interest in returning the patient's behavior to a level acceptable to society outweighed the lawfully committed patient's due process liberty interest).

While state legislatures have been silent on this issue, the ADA implies congressional disapproval of such medical coercion. Perhaps without even intending to, the ADA's nondiscriminatory stance may have limited the state's traditional parens patriae power over persons with mental illness since "it is hard to conceive of a state rationale for forcing a competent person with a mental illness to take medication while permitting a competent patient without a mental illness to retain individual choice." Milstein et al., supra note 6, at 1247. It would not be surprising if the ADA informed future litigation concerning the medication rights of institutionalized mentally ill patients.

${ }^{166}$ See Parry, supra note 149, at 106. For a critical discussion of the ADA's impact on health insurance for persons with mental illness, see generally Giliberti, supra note 
EEOC, nor the courts have addressed this issue, this Comment argues that the employer should provide these benefits. as long as such a request is "reasonable." What is reasonable for one employer may present an undue hardship for another; thus, the answer to the question of whether the employer can bear this cost will depend on the circumstances of each case.

\section{CONCLUSION}

Even as we applaud Congress for the ADA, we "must never believe our goal has been reached." 167 The passage of the ADA counters a historical "hierarchy of personhood, with the attributes of full citizenship vested only in those who satisfy a standard of mental fitness." While the ADA sends a message of emancipation to the mentally ill, the courts must work together with the EEOC to ensure that disparate application of the ADA does not thwart its ideals. The employer's responses to perceived threats in the workplace and the use of psychotropic medication present two of the greatest challenges for the application of the ADA to the mentally ill. Although current standards attempt to protect the mentally ill from unwarranted use of the safety defense, the present direct threat standards fail. Silence on the issue of psychotropic medication leaves the EEOC interpretation unfinished, especially if the current risk-to-self-or-others standard passes judicial muster. Ultimately, the law must recognize the medical advances that confront the mentally ill in society. The ADA does not merely propose legal tolerance of the mentally ill, it envisions their societal empowerment. In order to protect and empower the mentally ill and provide employers with useful guidelines regarding their employment, our standards must reflect an understanding of the complexity and nuances of the issues presented by the safety defense.

149 (arguing for revision in the EEOC's health insurance guidance).

${ }^{167}$ Nosek, supra note 32, at 466.

${ }^{168}$ Steven J. Schwartz, Abolishing Competency As a Construction of Difference: A Radical Proposal to Promote the Equality of Persons with Disabilities, 47 U. MIAMI L. REV. 867, 868-69 (1993). 
